\title{
VÁZLATOK ÉS BESZÉDTÖREDÉKEK A SZENVEDÉLYRÖL: AZ ERÓTIKA PATHÉMATA ÉS A GEORGICA SZERELMI MÍTOSZAI
}

\begin{abstract}
A Georgica legvégének dulcis alebat Parthenope sorát (IV, 563-564) a Serviusig visszanyúló olvasati hagyomány hol a Szirének egyikével, Neapolis/Parthenopolis védőistenségével hozza kapcsolatba; hol a szűzi tisztasága miatt Partheniasnak nevezett költőre utaló autoreferenciális játékot vél felfedezni benne. Az életrajzi és a lokális tradíción alapuló korábbi értelmezések kiegészítéséül a tanulmány a hely metapoetikus olvasatának lehetőségét veti fel. Parthenope megidézése a sphragisban az erotikus elbeszéléseiben a mítosz megújításával kísérletező, Vergiliusszal és Galluszal szoros kapcsolatban álló Parthenios előtti tisztelgésként is értelmezhető. Az Erótika pathémata latin utóéletének kutatása döntően az elegikusokra és Ovidiusra korlátozódik, noha a Georgica rejtett mitológiai allúzióinak hátterében ugyancsak jellegzetes partheniosi narratív sémák sejlenek fel. Vergilius rövid, többnyire szerelmi szenvedéstörténeten alapuló aitionjai tekinthetők egyes partheniosi történetvázak erkölcsi téttel kiegészülő, egységes világképbe rendeződő újraírásának is.
\end{abstract}

Kulcsszavak: Parthenios, Erótika Pathémata, Vergilius, Georgica

1.

A Georgica zárásában, a teljes életmü egyetlen, a költő személyét nyíltan említő helyén Vergilius az édes dajka, Parthenopé tápláltjaként jeleníti meg önmagát (IV, 563-564): Illo Vergilium me tempore dulcis alebat / Parthenope studiis florentem ignobilis oti. A hely értelmezése távolról sem egységes. Míg egyesek olvasatában a sphragis mitológiai allúziója az ember halandó természetét és annak elidegeníthetetlen részeként a szenvedést állítja középpontba, mások szerint e sorok a költő számára oly kedves campaniai tájat idézik meg. ${ }^{1}$ Servius kommentárja alapján a Parthenope alak Nápolyra, ${ }^{2}$ az egykori Parthenopolisra s annak védőistenségére utal, ${ }^{3}$ akit a hagyomány a Szirének egyikével azonosít. Parthenopé Itáliába érkezésének körülményei vitatottak az antikvitásban. Dél-itáliai kultuszát a hellénisztikus verzió Odysseus és a tenger halálos énekeseinek konfliktusára vezeti vissza: a büvös énekű madárlányok, miután hiába próbálják megakadályozni Ithaka urának hazatérését, szégyenükben öngyilkosok lesznek, s egyi-

${ }^{1}$ G. M. Miles: Virgil's Georgics. Berkeley 1980. 293, illetve M. Erren: Vergilius Maro. Georgica II. Heidelberg 2003. 1002.

2 Servius ad Georg. IV, 563: Parthenope: id est Neapoli, quae primo ex corpore unius sirenis illic sepultae Parthenope est appellata. A kommentárt az alábbi kiadásból idézem: G. Thilo - H. Hagen: Servii Grammatici qui feruntur in Vergilii carmina commentarii. Leipzig 1881.

${ }^{3}$ A város neve a pseudo-vergiliusi Etna kivételével (430: Neapolis) nem szerepel a költeményekben. 
kük hullámok dobálta holtteste a Nápolyi-öbölben talál végső nyughelyre. ${ }^{4}$ Vergiliusnál magánál csupán a Szirének emlékével találkozni. A trójaiak ugyan elhajóznak a valaha általuk lakott, pontosan nem lokalizált szirt mellett, éneket azonban ekkor már nem hallani, csak a sziklákra csapódó hullámokat. ${ }^{5}$ A táj ennek ellenére őriz még valamit egykori varázserejükből: e térségben tűnik el ugyanis Palinurus (V, 833-863), aki a fáradt kormányost álomra csábító, hangjával és szárnyaival egyaránt a Szirénekre emlékeztető Somnus hatására hull a mélybe. ${ }^{6}$

Mindazonáltal több okból feltételezhető, hogy Parthenopé megidézése a Georgica legvégén metapoetikus jelentőséggel is bír, hiszen a Szirének, a Múzsák sötét rokonai, baljós énekükkel a költészet sajátos fajának képviselői. ${ }^{7}$ Ugyancsak a szerzői önreflexió szándékának feltételezését erősítheti a mítosz halott énekesnőjének neve: a Parthenope alak a hangzásbeli hasonlóság $\mathrm{s}$ a benne rejtőző köznévi jelentés $(\pi \alpha \rho \theta \varepsilon \dot{\varepsilon} \nu \varsigma=$ szűz) alapján a költő életrajzi hagyományában rendre a Vergilius ragadványneveként ismert Parthenias formával társítva jelenik meg. A Lány (a Szirén vagy maga Persephoné, a

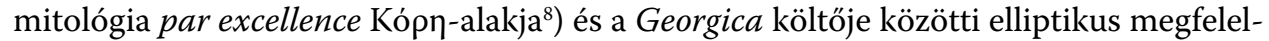
tetésként értelmezi a helyet M. Korenjak is, aki szerint a IV. könyv végi Parthenope az I. könyv 429. sorának virgineum szavára válaszol: a két, azonos szemantikai mezőbe tartozó alak együttese ezáltal kettős, mitológiai-önéletrajzi utalással keretezi a művet. ${ }^{9}$

A hellénizmus aitiológiai érdeklődését idéző késő antik és középkori források többségükben egyetértenek abban, hogy a Parthenias/Partenius/Partenose s egyéb alakváltozatokban ismert ragadványnév a költő feddhetetlen erkölcseire megy vissza. ${ }^{10}$ Servius egy ritkán említett, a jelen vizsgálat szempontjából azonban elsődleges fontosságú apró megjegyzése valamelyest módosíthatja a költő tisztaságát övező általános csodálatot. A kommentáríró egy elejtett mondatban Vergilius vággyal szembeni beteges kiszolgál-

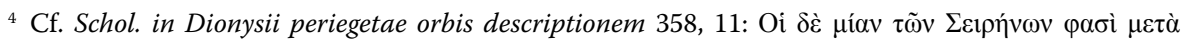

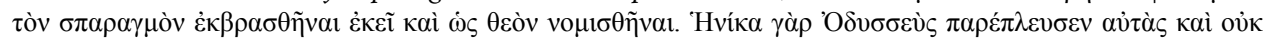

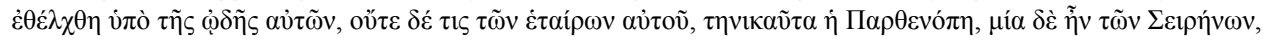

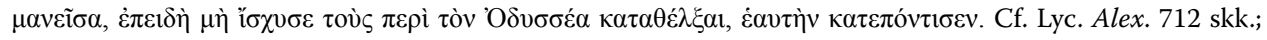
Strab. Geogr. V, 4, 8; VI, 1, 1.

${ }^{5}$ Cf. Aen. V, 864-866: Iamque adeo scopulos Sirenum advecta subibat, / difficilis quondam multorumque ossibus albos, / tum rauca adsiduo longe sale saxa sonabant (...) Ugyancsak a Szirének pusztulására utalhat ugyanezen ének 556. sora, ehhez lásd S. Kyriakidis: Fractasque ad litora voces. REA 203 (2001) 481 skk.

${ }^{6}$ Vö. D. Nelis: Vergil's Aeneid and the Argonautica of Apollonius Rhodius. Leeds 2001. 205 skk.

7 A Jenseitsmusen képzetéhez lásd M. Egeler: Walküren, Bodbs, Sirenen. Gedanken zur religionsgeschichtlichen Anbindung Nordwesteuropas an den mediterranen Raum. Berlin - New York 2011. 407 skk.

${ }^{8}$ Apollónios Rhodios szerint (Arg. IV, 896) a Szirének Persephoné dalos társnői annak elrablása előtt.

9 M. Korenjak: Parthenope und Parthenias: zur Sphragis der Georgika. Mnemosyne 48 (1995) 201 sk. A szüzességgel kapcsolatos szójáték olvasható az Aeneisben is, vö. A. Cucchiarelli: Vergil on Killing Parthenius (Aen. 10. 748). CJ 97 (2001) 51 skk.

${ }^{10}$ Cf. Serv. Vita Verg. 1: adeo autem verecundissimus fuit, ut ex moribus cognomen acciperet; nam dictus est Parthenias, omni uita probatus. Cf. Vita Monacensis II: fuit enim excellenti ingenii et tantae admiracionis quod ab omnibus Parthenius diceretur, id est bene tenens vel perciens, vel a Partenose, id est cum virtute probatus. A vitákat az alábbi kiadásból idézem: J. M. Ziolkovski - M. C. J. Putnam: The Virgilian Tradition: The First Fifteen Hundred Years. New Haven - London 2008. 203, 270. 
tatottságára utal, s ezáltal bizonyos mértékben megkérdőjelezi a ragadványnév görög etimológiája sugallta lányos ártatlanság gondolatát: (...) uno tantum morbo laborabat; nam impatiens libidinis fuit. ${ }^{11} \mathrm{Az}$ impatiens libidinis szerkezet jelentése nem egyértelmü: a parthenos Vergilius sztereotípiájához igazodva kifejezheti a testi szenvedélytől való teljes mentességet, meg nem érintettséget - amiként arra lexikális párhuzamot látni Ovidius impatiens expersque viri Daphnéja esetében (Met. I, 479). Donatus, Laetus és különösképp az ezen összefüggésben a morbus fogalmát használó Servius azonban sokkal inkább a költő féktelen szenvedélyére tünik utalni. ${ }^{12}$ Vergilius erőteljes érzékiségének az életrajzokban többnyire elhallgatott motívuma mindazonáltal nem zárja ki a sphragisban olvasható, Vergiliust a szűz Parthenopéval társító gondolat létjogosultságát sem, hiszen az erotika a Szirének mítoszának is szerves részét képezi. ${ }^{13}$ A kizárólag férfiakat veszélyeztető, ellenállhatatlan női hanghoz magától értetődően kötődik a csábítás, az erotikus birtokbavétel képzete, amint arra korábban Apollónios Rhodios is utal. Az Argonautika IV. könyvében (a Szirének haláláról közvetlenül nem nyilatkozó) epikus a madárlányok vereségét az Odysseia elbeszélésénél korábbi mitológiai rétegbe helyezi: a tenger énekesnőit Orpheus némítja el egy vad és hangos zenei agón során, amely-

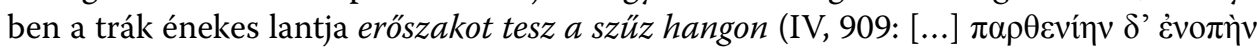

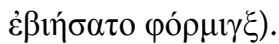

Parthenopé és Vergilius összetartozását erősítheti a dél-itáliai lokális hagyomány is. Az egykori Parthenopolist az Actiumnál győztes Octavianus parancsára alapítják újjá s nevezik át Neapolisnak. ${ }^{14}$ A város nem csupán a fiatal Vergilius otthona, de menedék a nyilvánosságot kerülő, érett költő számára is; mi több, Suetonius szerint (Vita Verg. 11) a Parthenias ragadványnév is e környéken használatos eredetileg: cetera sane vitae et ore et animo tam probum constat, ut Neapoli Parthenias vulgo appellatus sit. Vergilius gyakori parthenopolisi időzése tekinthető az Augustus Rómájától való tudatos távolmaradásnak is, amint arra a császár egyik, a költőhöz intézett üzenetéből következtetni lehet. A levélíró ebben méltatlankodásának ad hangot amiatt, hogy Vergilius feltűnő s érthetetlen sietséggel hagyta el a campaniai várost az uralkodó közeledtének hírére. ${ }^{15} \mathrm{~A}$ poéta és Nápoly kötődésének igazolására ezeken túl említhetnénk még a várost óvó Parthenopé és a későbbi századok emlékezetében ugyancsak természetfeletti erővel rendelkező, hatalmát szintén Parthenopolis/Neapolis javára fordító varázsló-Vergilius lokális kultu-

${ }^{11}$ Az impatiens libidinis Vergilius képzetének további előfordulásait lásd Ziolkovski - Putnam: i. m. (10. jegyz.) 203, 231, 307, 399, 713.

12 A Vergilius nemiségével kapcsolatos antik tradícióról, annak későbbi cenzúrázásáról lásd $F$. Stock: Virgil's Biography Between Rediscovery and Revision. Renaissanceforum 9 (2015) 63 skk., itt 79 skk.

13 A Szirén mint erotic women: Miles: i. m. (1. jegyz.) 293, 35. jegyzet.

${ }^{14}$ A forrásokat lásd L. Miletti: Setting the Agenda: The Image of Classical Naples in Strabo's Geography and Other Ancient Literary. In: Remembering Parthenope: The Reception of Classical Naples from Antiquity to the Present. Eds. J. Hughes - Cl. Buongiovanni. Oxford 2015. 19 skk., itt 248.

15 Epist. 35. Malcovati: excucurristi a Neapoli. A témához lásd R. F. Thomas: Virgil and the Augustan Reception. Cambridge 2001. 38 skk. 
szának párhuzamait is. ${ }^{16}$ Az eddigiek alapján tehát joggal feltételezhető, hogy a Georgica szerzőjének mű végi önarcképe, amely az ellenállhatatlan dalú neapolisi Szirén neveltjeként láttatja az alkotót, metapoetikai fontosságú hely, amelynek személyes vonatkozását és esztétikai jelentőségét a $562-565$. sorok otia telestichonja is kiemelni látszik. ${ }^{17}$

A mítosz énekesnőjén túl a tanköltemény zárósorai azonban egy valós, történeti hitelü alkotót is idézhetnek, a nikaiai Partheniost, akire az irodalomtörténeti hagyomány a hellénizmus művészetének legfőbb római közvetítőjéként tekint. Parthenios alakja a nevek akusztikai hasonlóságán túl más okból is társítható Parthenopéval és Parthenias-Vergiliusszal: az életrajzi tradíció szerint a fiatal latin költő és a nála lényegesen idősebb görög irodalmár első találkozására az akkor még Parthenopolis nevű városban került sor. ${ }^{18}$ Jelen tanulmány a sphragis ezen metapoetikus olvasata mellett igyekszik érvelni, amelynek értelmében Parthenopé megidézése az inspirációval kapcsolatos önreflexív állásfoglalás része. Olvasatomban a dulcis alebat Parthenope kijelentés utólagos szerzői kommentárként, mintegy hermeneutikai kulcsként értelmezendő, amely egyrészt a mítosz irodalmi megközelítésnek új lehetőségeire hívná fel az olvasó figyelmét (számos, az alábbiakban tárgyalandó részlet mellett lásd mindenekelőtt az ihletadó Múzsa hagyományos szerepében feltűnő Szirént). Másrészt valamiféle hommage-nak tekinthető Parthenios és (a Vergiliusszal közös barátnak, Cornelius Gallusnak ajánlott) műve, az Erótika pathémata iránt. Utóbbi irodalmi programja (görög) mítoszok (latin) újraírását tűzi ki célul, s mint ilyen, esetenként a Georgica többé-kevésbé rejtett mitológiai utalásainak egyik lehetséges forrása/modellje is lehet, hiszen a görög gyüjtemény jellegzetes történetsémái, egyes személynevei, mint azt az alábbiakban igazolni igyekszünk, több alkalommal felbukkannak a mezőgazdaságról szóló latin tankölteményben. Egy ilyesfajta, Partheniost idéző metapoetikus nyelvi játék feltételezésének jogosságát további, a kutatásban régóta jegyzett párhuzamok támaszthatják alá. A Gallusnak emléket állító X. eclogában szereplő Parthenios (...) circumdare saltos kifejezés (57) megfontolandó érvek alapján szintén a Parthenios, Parthenias-Vergilius és Cornelius Gallus közötti emberi és

${ }^{16}$ Lásd pl. a relikviákhoz kötődő legendák egy további párhuzamát: csakúgy, mint a Sziréné, a Brundisiumban elhunyt költő földi maradványai is translatio eredményeképp kerülnek végső nyughelyükre. A Cronaca di Partenope lapjain feljegyzett, Vergilius által véghez vitt csodák listáját lásd Ziolkovski - Putnam: i. m. (10. jegyz.) 945 skk. Lásd még G. Abbamonte: Naples - A Poet's City. Attitudes towards Statius and Virgil in the Fifteenth Century. In: Hughes - Buongiovanni: i. m. (14. jegyz.) 170 skk. Megjegyzendö, hogy Vergilius szerelmi bájitalok mestereként is ismert, vö. Stock: i. m. (12. jegyz.) 79.

${ }^{17}$ A telestichon kapcsán újabban lásd D. Nelis: Vergils' Library. In: A Companion to Vergil's Aeneid and Its Tradition. Eds. J. Farrel - M. C. J. Putnam. Chichester - Malden MA 2010. 11 skk., itt 21, illetve J. Danielewicz: Vergil's certissima signa Reinterpreted: The Aratean lepte-acrostic in Georgics I. Eos 100 (2013) 287 skk.

${ }_{18}$ A vitatott mester-tanítványi viszonyról lásd E. Calderon Dorda: Partenio, maestro de Virgilio. In: Simposio virgiliano conmemorativo del bimilenario de la muerte de Virgilio. Murcia 1984. 217 skk.; újabban J. L. Lightfoot: Parthenius of Nicaea. The Poetical Fragments and the Erotika pathemata. Oxford 1999. 14 skk., $70,165,168$ skk. 
művészi kapcsolatra utalhat; ${ }^{19}$ a VI. ecloga számos, a Georgicában is feltűnő görög mítoszt megéneklő agg Silénosát ugyancsak Partheniosszal szokás azonosítani, s lexikális egyezés alapján szintén a görög költő alakját látja a kutatás a vers végén a pásztorfiúknak (Gallusnak és Vergiliusnak?) sípot ajándékozó és őket költővé avató Linusban. ${ }^{20}$

2.

Parthenios kevéssé ismert életműve a görög és a latin kultúra, a kései köztársaság és a császárkor határmezsgyéjén helyezkedik el. Fehér foltokkal teli életrajza szerint amely csupán találgatásokra ad lehetőséget - a görög költő Kr. e. 73 körül érkezik Rómába, a mithridatési háborúk hadifoglyaként. Műveltségének köszönhetően felszabadul a rabszolgasorból, s hamarosan a város irodalmi életének ismert szereplője lesz, kitűnő kapcsolatokat ápolva a korszak philhellén alkotóival, főként a fiatal Cornelius Galluszszal és Vergiliusszal. ${ }^{21}$ A személyes, egzisztenciális függetlenségét és művészi önállóságát megőrző Parthenios grammaticusi minőségben leginkább irodalmi, mitológiai szakértőként, tanácsadóként mủködhet a latin költészet új hullámának alkotói mellett - tevékenységét a korábban feltételezett görögtanárságra korlátozni az újabb vizsgálatok tükrében hibás elképzelés. ${ }^{22}$

Parthenios kultúraközvetítői szerepét és műveinek hatását tekintve a szakirodalom máig megosztott. ${ }^{23}$ A XIX. század közepére visszavezethető elemzések tükrében a poetae novi számára legfőbb modellnek bizonyuló Kallimachost ${ }^{24}$ és Euphoriónt Rómá-

19 Vö. J. O'Hara: True Names. Vergil and the Alexandrian Tradition of Etymological Wordplay. Ann Arbor 1996. 252; G. O. Hutchinson: Greek to Latin: Frameworks and Contexts for Intertextuality. Oxford 2013. 16.

${ }^{20}$ A Grynei nemoris (VI, 72) szerkezetben szereplö, az Aeneisben (IV, 345) is olvasható apollóni epitheton esetleges partheniosi eredetéről (fr. 10) lásd Lightfoot: i. m. (18. jegyz.) 150-151. A VI. ecloga említett helyeihez lásd B. Otis: Vergil: A Study in Civilized Poetry. Oxford 1964. 138 skk., újabban S. J. Harrison: Generic Enrichment in Vergil and Horace. Oxford 2011. 47 skk.

${ }^{21}$ A költő életrajzi vázlatát lásd Lightfoot: i. m. (18. jegyz.) 9 skk.; Ch. A. Francese: Parthenius of Nicaea and Roman Poetry. Frankfurt 2001. 17 skk.

${ }^{22}$ Cf. Macr. Sat. V, 17, 18 (= T 9a Lightfoot), lásd még Lightfoot: i. m. (18. jegyz.) 85. A grammaticus fogalmának felülvizsgálatát lásd Francese: i. m. (21. jegyz.) 37 skk.

${ }^{23}$ A kutatástörténeti összefoglalókat lásd Lightfoot: i. m. (18. jegyz.) 50 skk.; Francese: i. m. (21. jegyz.) 9 skk., illetve Harrison: i. m. (20. jegyz.) 47 skk. Két példa az utóbbi évek álláspontjának szemléltetésére: az A. Zucker szerkesztette, a Parthenios-kutatást új alapokra helyező tanulmánykötetben (Littérature et érotisme dans les Passions d'amour de Parthénios de Nicée. Actes du colloque de Nice, 31 mai 2006. Grenoble 2008) Vergilius neve csak kétszer szerepel (11: P. mint Vergilius görögtanára, 196: az Oinoné-mítosz). Ph. Thibodeau monográfiája részletes érvelés nélkül von párhuzamot a természettudományos/mitológiai ismereteket tömör, tényszerű formában közlő aristotelési/partheniosi források és az azok adatait művészi formában kidolgozó Vergilius és Gallus (?) között, lásd Playing the Farmer: Representations of Rural Life in Vergil's "Georgics”. Berkeley - Los Angeles - London 2011. 281, 21. jegyzet.

${ }_{24}$ Parthenios költészetéről általában lásd Lightfoot: i. m. (18. jegyz.) 16 skk.; a kallimachosi hatásról lásd T 5, 6 Lightfoot, illetve M. Fantuzzi - R. Hunter: Muse e modelli. Roma - Bari 2002. 336. 
val megismertető Parthenios a latin költészet megújulásának megkerülhetetlen egyénisége, akinek alkotásai döntő hatással voltak jellegzetes római műfajok létrejöttére. ${ }^{25}$ Parthenios esztétikai mindenhatósága azonban jelentős mértékben megkérdőjeleződik az újabb elemzésekben, amelyek szerint a hellénizmus római divatja nem köthető kizárólag egyetlen görög szerző személyes jelenlétéhez. ${ }^{26}$ A görög szerző művészetéről a csaknem egészében elveszett lírai életmü törmelékei alapján (az újabban előkerült papiruszleletek ellenére sem) alkotható helytálló és végleges ítélet. Egyetlen, kisebb lacunáktól eltekintve sértetlenül ránk maradt műve, az Erótika pathémata emiatt is kiemelkedő fontosságú, mivel úgy tűnik, hogy a szerző, vitathatatlan kallimachosi vénája ellenére, ${ }^{27}$ olyan művet kínál elbeszélésvázlataival, amely a mítosz szokatlan megközelítése és ízlésbeli sajátosságai alapján több ponton eltér az Aitia hirdette irodalomeszménytől.

Ahelyett, hogy bizonytalan feltételezésekbe bocsátkoznánk a Calvus, Cina és Gallus elveszett epyllionjait és elégiáit érintő partheniosi hatásról, ${ }^{28}$ az alábbiakban két, egészében hagyományozott szöveg, az Erótika pathémata és a Georgica mitológiai utalásainak egybevetésére vállalkozunk. Az első pillantásra igénytelen stílusú synopsis-gyüjtemény és a Vergilius által egyetlen, valóban befejezett, ultima manus illette művének tekintett tanköltemény rokonítása meglepőnek tűnhet, noha a két mű között számos, alaposabb vizsgálatra ösztönző közös vonás fedezhető fel.

A partheniosi gyűjtemény ajánlólevele Cornelius Gallushoz szól. Octavianus egykori hű szövetségese, az Antonius elleni harcokban magát kitüntető s emiatt fontos pozíciót elnyerő költő Actium után néhány évvel politikai intrikák áldozataként kegyvesztett lesz. A száműzetéssel, vagyonelkobzással, a lovagi rendből s Augustus házából való kitiltással sújtott Gallus 27-ben vagy 26-ban öngyilkosságot követ el, megpróbáltatásai azonban ekkor sem érnek véget: a damnatio memoriae alakját mindörökre törölni kívánja a római emlékezetből. Ami Partheniost illeti, sorsának alakulása az augustusi regnum idején nem ismeretes, ami azért is meglepő, mert a császár utódai, talán a hellénizmus hivatalos, intézményesített költőkultuszát imitálva, felettébb nagyra értékelik: Tiberius a költő portréját (más alkotókéval együtt) elhelyezteti a közkönyvtárakban, Hadrianus parancsot ad sírja felújítására. ${ }^{29}$

A partheniosi gyűjteményt és a tankölteményt összekötő elemeket keresve nyilvánvalóan megkerülhetetlen a laudes Galli problematikája. A Kr. e. 29 nyarán befejezett s Augustusnak felolvasott Georgica a szakirodalomban sokáig a renovatio imperii művészi kidolgozottságú propagandaanyagaként szerepelt. Az uralkodó által beveze-

${ }^{25}$ Lásd főként az Areté-epicedium és a római szerelmi elégia kapcsolatának kérdését, vö. Th. Gartner: Überlegungen zur Genese der römischen Liebeselegie aus der hellenistischen Dichtung. AAntHung 46 (2006) 213 skk.

${ }^{26}$ N. B. Crowther: Parthenius and Roman Poetry. Mnemosyne 29 (1976) 65 skk.; hasonlóképp Fantuz$z i-$ Hunter: i. m. (24. jegyz.) 537. Callimachea.

${ }^{27}$ Lásd A. Cameron Lightfoot: i. m. (18. jegyz.) által mottóként idézett formuláját: anima naturaliter

${ }^{28}$ Minderről lásd A. S. Hollis: Fragments of Roman Poetry C. 60 BC-AD 20, Oxford 2007. 238 skk.

29 T 3-4 Lightfoot. 
tett politikai, gazdasági és ideológiai változások célja az irodalomtörténeti konszenzus szerint a polgárháborúban súlyos sebeket szerzett társadalom talpra állítása, a rómaiak visszavezetése a mos maiorum értékrendjéhez és egyfajta idealizált, tiszta, mértékletes és egyszerü életmódhoz, amelynek alappillére a földművelés. A Vergilius-interpretáció évszázadaira mindvégig ható, a jelen vizsgálat szempontjából is kiemelkedő fontosságú Servius azonban olykor igen kétértelmű mondatokban fogalmaz a mű egyes, általa inkább antiheroikusnak, mintsem hősinek érzett részletei kapcsán: a kommentáríró a költemény aulikusnak tekintett föszólama mögött olyan titkos hangokat is hallani vél, amelyek szemlátomást ellentétesek a hivatalos augustusi ideológiával. ${ }^{30}$ Ezen kétértelmü helyek legfontosabbja a 29 augusztusában befejezett tanköltemény IV. könyvének zárórésze, amely Servius szerint az elhunyt Gallus emlékét idézte volna, s amelyet a költő, Augustus határozott parancsának engedelmeskedve, Orpheus és Eurydiké tragikus mítoszával helyettesített. ${ }^{31}$ Noha az adat megbízhatósága pusztán kronológiai megfontolásokból is kétséges, a zárómítosz allegorikus olvasata mindmáig jelen van az értelmezésekben: Orpheus nem más, mint Gallus, míg Aristaeus, az isteni méhész a kortárs római kaptár urát testesítené meg. ${ }^{32}$

A jelen vizsgálat célja nem a költő és az uralkodó viszonyának, ${ }^{33}$ a Georgica IV. éneke esetleges átírásának újratárgyalása, sem pedig a sokforrású mű nyilvánvaló metagenerikus jellegének elemzése ${ }^{34}$ célunk kizárólag a partheniosi elbeszélésvázlatok és a tanköltemény még inkább fragmentumszerü mitológiai utalásainak összevetése. Úgy tűnik, Gallus személyén túl tematikai, esetenként atmoszférabeli hasonlóság is összeköti a nyelvi megformáltság, kidolgozottság szempontjából erősen különböző két művet, ami számos kérdést vet fel. Állítható-e, hogy Vergilius elliptikus szerelmi mítoszai a Parthenios által felkínált újraírás lehetőségével élnek, miként az később, Ovidius esetében joggal feltételezhető? ${ }^{35}$ Beszélhetni-e az elrejtettségük, minimális terjedelmük ellenére mélyebb etikai beágyazottságúnak tűnő vergiliusi allúziók és a morális állásfoglalást mellőző partheniosi narrációk világképbeli hasonlóságáról? Az Erótika pathémata elbeszéléseihez hasonlóan a Georgica mitológiai allúzióinak döntő többsége a szenvedély irracionális, legyőzhetetlen, házasságtöréshez, vérfertőzéshez, gyerekgyilkossághoz vezető erejét állítja a középpontba. Miként lehet a parthenopolisi otium idején írott tan-

30 Bővebben lásd Thomas: i. m. (15. jegyz.) 93 skk.

${ }^{31}$ Cf. Serv. ad. Georg. IV, ad Ecl. X, 1. A laudes Galli kutatástörténetéhez R. F. Thomas: Virgil, Georgics. Cambridge 1988. 13 skk. A Corpus Servianumról lásd D. Fowler: The Virgil Commentary of Servius. In: The Cambridge Companion to Virgil. Ed. Ch. Martindale. Cambridge 1997. 73 skk., illetve Harrison: i. m. (20. jegyz.) 165.

${ }^{32}$ Lásd pl. L. Cadili: Viamque adfectat Olympo. Memoria ellenistica nelle „Georgiche” di Virgilio. Milano 2001.

33 Újabban Thomas: i. m. (15. jegyz.) 25 skk.

${ }^{34}$ Erről legutóbb Harrison: i. m. (20. jegyz.) passim.

${ }^{35}$ Lásd föként J. Fabre-Serris: Histoires d'inceste et de furor dans les Métamorphoses 9 et dans le chant en catalogue d'Orphée: une réponse d'Ovide au livre 4 des Géorgiques. Dictynna 2 (2005), hozzáférhető: http://dictynna.revues.org/125; J. Fabre-Serris: Ovide, lecteur de Parthenios de Nicée. In: Zucker: i. m. (23. jegyz.) 189 skk. 
költemény korántsem szelíd vagy higgadt mítoszait elhelyezni az Augustus-kor formálódó erkölcsi kontextusában, amely a negotium fogalmával szorosan összetartozó, józan, engedelmes, felelősségteljes és feddhetetlen magánéletet, a házasság, a család mindenek feletti értékét helyezi előtérbe?

Mindezen kérdések tárgyalásához a művek általános jellemzőinek bemutatása szükségeltetik. A vélhetően Kr. e. 52-26 között keletkezett partheniosi gyűjtemény 36 kevéssé ismert szerelmi mítosz tömör, lecsupaszított vázát közli. A cselekményességre összpontosító szövegek többnyire igen gyors tempóban közelednek az adott elbeszélések dramaturgiai végkifejletéhez, mellőzve a kitérőket, leírásokat, párbeszédeket. ${ }^{36}$ Parthenios mítoszait főképp a hellénizmus történetíróitól és költészetéből kölcsönzi, noha elbeszéléseinek egy része a homérosi tradícióhoz kapcsolódik, egyfajta, az eposzokhoz készült sajátos, erotikus széljegyzet gyanánt. ${ }^{37}$ A kötet egésze a görög mitológia alapvető jegyeiben rejlő esztétikai lehetőségeket tűnik kiaknázni. Mint az közismert, hivatalos corpus híján a mítosz csupán irodalmi allúziókban él, s az egyes feldolgozások, tartózkodva egy-egy történet teljes, végleges változatának rögzítésétől, nyitva hagyják a mindenkori átírás, a nézőpontváltás, az új, esetenként váratlan összefüggések tudatosításának lehetőségét. ${ }^{38}$

A Gallusszal esetleg erotikus kapcsolatban is álló Parthenios vázlatai szemlátomást ugyanezen elven működnek. ${ }^{39}$ A gyűjtemény részint a latin költő majdani epikus és elégikus müveihez kínál kidolgozandó alapanyagot. ${ }^{40}$ A grammaticus további célja feltehetőleg a ritkábban tárgyalt mítoszokban való általános eligazodás segítése; elbeszélései végezetül kielégíthetik a bizarr, vagy olykor kifejezetten perverz történetekre vágyó közönség igényeit is. Az Erótika pathémata a múltban sokszor elvitatott irodalmi igényessége az utóbbi időben mindenekelőtt a francia kutatás révén nyert bizonyítást. A szerkezetre, elbeszélői stratégiára irányuló vizsgálatoknak köszönhetően a sorozat immáron határozott esztétikai elveket követő, tudatosan összeállított műként jelenik meg. A korábban minimális írói ambícióval létrehozott, ${ }^{41}$ belső logikát nélkülöző konglomerátumnak tekintett szerény kis opus mára a varietas és az elliptikus szövegalkotás

${ }^{36}$ Bővebben lásd G. Spatafora: Les Erotica Pathémata de Parthénios et la réécriture en format abrégé. In: Zucker: i. m. (23. jegyz.) 27 skk.

37 A homérosi kontextusról lásd A. Billault: La littérature dans les Erotica Pathémata de Parthénios. In: Zucker: i. m. (23. jegyz.) 17 skk.; E. Sistakou: Reconstructing the Epic. Cross-Readings of the Trojan Myth in Hellenistic Poetry. Leuven 2008. 136.

38 Vö. A. Cameron: Greek Mythography. Oxford 2004. 237 sk.

39 A gyűjteményről mint az غ̇pó $\theta \eta \varsigma$ Parthenios által Gallusnak ajánlott szerelmi zálogról lásd A. Francese: Lérotisme dans les Erotica Pathémata de Parthénios. In: Zucker: i. m. (23. jegyz.) 163 skk.

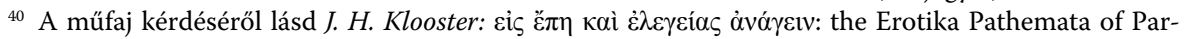
thenius of Nicaea. In: Brill's Companion to Greek and Latin Epyllion and Its Reception. Eds. M. Baumbach - S. Bar. Leiden - Boston 2012. 309 skk.; Harrison: i. m. (20. jegyz.) 69.

41 Cf. Cameron: i. m. (38. jegyz.) 272. 
elveire épülő, a figyelmes olvasó közreműködésére számító alkotásnak tűnik;42 $\mathrm{S}$ ami régebben meglehetősen lapos, száraz és kevéssé gondozott szövegnek látszott, az újabban a prózavers korai kísérletének számít. ${ }^{43}$

Parthenios mítoszait sajátos, a heroikus tradíciótól élesen eltérő fényben láttatja. ${ }^{44}$ Noha számos szereplőjét (Achilleus, Odysseus, Paris) a Trója-mítoszból vagy a görög történelemből (Periandros, Kroisos) kölcsönzi, a szerző nem beszél háborúról, hódításokról s egyéb hősies, férfias vállalkozásokról, hogy azok helyett az érzelmekre

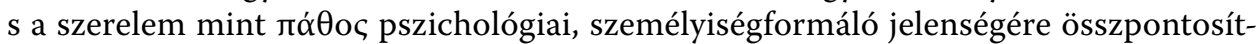
son. A szerző az érzékiség lélekre gyakorolt hatását kutatva gyakran iszonyatos bűntetteket, természetellenes megnyilvánulásokat állít a középpontba, amelyek erkölcsi minősítése (néhány kivételes esettől eltekintve) rendre elmarad. Az erotikus viselkedés változatos mintázatait megjelenítő toposzai, ${ }^{45}$ valamint kivonatoló, vázlatszerű formája révén a gyűjtemény a műfajok, a nyelvek és a kultúrák közötti átjárást biztosító újraírás képviselője. ${ }^{46}$

Az Erótika pathémata mértékadó modern kiadója szerint a Georgica egyetlen, az antik kommentárok által is bizonyítottan partheniosi eredetű helye az egysornyi tengeristen-katalógus (I, 437). ${ }^{47}$ Aulus Gellius és Macrobius e helyhez füzött megjegyzései tudatos, az aemulatio szándékával bővülő imitációról számolnak be - a hely esztétikai fontosságát, elméleti-önreflexív jellegét egyébiránt Vergilius nevének ugyanitt szereplő újabb acrostichonja is alátámasztja. ${ }^{48} \mathrm{~A}$ partheniosi és a vergilusi kompozíció motivikus hasonlóságainak elemzése előtt érdemes felidézni Gellius egy további meg-

${ }^{42}$ A gyűjtemény tematikus egységéről lásd Cadili: i. m. (32. jegyz.) 112, illetve Cameron: i. m. (38. jegyz.) 301. A tematikailag összetartozó elbeszélések egymástól való eltávolításának tendenciájáról $D$. Voisin: Dispositio et stratégies littéraires dans les Erotica Pathémata de Parthénios. In: Zucker: i. m. (23. jegyz.) 39 skk.

${ }^{43}$ Lásd M. Biraud: Échos imitatifs et transgressifs des poètes alexandrins dans les Erotica Pathémata 11 et 34 de Parthénios de Nicée. In: La variatio. L'aventure d'un principe d'écriture. Éd. H. Vial. Paris 2014. $103-115$.

${ }^{44}$ Vö. Francese: i. m. (21. jegyz.) 69 skk.

45 A főbb toposzokról (szexuális beavatás, vérfertőzés, házasságtörés, gyerekgyilkosság, nemi erőszak, öngyilkosság, törvénytelen gyerek, lelkifurdalás) és azok összekapcsolásának módjairól lásd főképp Voisin: i. m. (42. jegyz.) passim. Az incestus-motívum feltűnően erős jelenlétéről lásd Billault: i. m. (37. jegyz.) 23.

46 A regény és a tragédia hatásáról lásd Billault: i. m. (37. jegyz.) 21 skk.

${ }^{47}$ Lightfoot: i. m. (18. jegyz.) 165, 195, 297, 561. Daphné és Scylla történetének esetleges partheniosi előképe a kiadó szerint a pure conjectures kategóriájába sorolandó.

${ }^{48}$ A feltételezett $P U-V E-M A$ acrostichonról (I, 429-431-433) lásd O’Hara: i. m. (19. jegyz.) 37, illetve Nelis: i. m. (6. jegyz.) 22. A helyet Hutchinson: i. m. (19. jegyz.) 305 Vergilius esztétikai emancipációjának dokumentumaként értelmezi, aki a hésiodosi tradíciótól Aratos és Parthenios segítségével távolodik el. A helyhez lásd még L. Morgan: Patterns of Redemption in Virgil's Georgics. Cambridge 1999. 22, 40. 
jegyzését is, amely a vergiliusi fordítás, újraírás általános módszertanára vonatkozik. A római költő, olvasni a Noctes Atticae szerzőjénél, a szó szerinti fordítás helyett egyes elemeket kihagy görög modelljeiből, másokkal pedig bővíti azokat. ${ }^{49}$ Szempontunkból ez a fajta rugalmasság igen nagy jelentőségű, a földművelésről szóló tankölteményben ugyanis a tengeristenek felsorolásán kívül sem idézeteket, sem olyan lexikai egységeket, szófordulatokat nem találni, amelyeket bizton Partheniostól átvett vagy általa ihletett helyeknek tekinthetnénk. Ennek megfelelően az alábbiakban tematikus egyezésekre koncentrálunk, a két szerzőnél egyaránt előforduló motívumokra, cselekménybeli rokonságra. E módszer jogosultságát Clausen mára klasszikus jegyzete igazolhatja, amely a szóhasználati megfelelések hiánya ellenére is meggyőzően érvel Dido IV. énekbeli halálának partheniosi eredeztetése mellett. ${ }^{50}$ Karthagó királynője az Aeneastól kapott tárgyakkal körülvéve követ el öngyilkosságot, miként az Erótika pathémata II. fejezetében Aiólos szélisten lánya, a csalárd Odysseus által elcsábított Polymélé ugyancsak egy, váratlanul távozó szeretőjétől (s közvetetten Trójából) származó, meg nem nevezett tárgyat szorít magához a halálra készülve - a tárgy mibenlétét majd a történetet újramesélő Gallusnak kell meghatároznia. Ezen motivikus hasonlóság ellenére a két jelenet végkifejlete ellentétes: szemben Dido tragikus végzetével, a bősz apja által halálra szánt megesett lányt saját fivére vérfertőző szerelme menti meg s vezeti (a család által jóváhagyott) boldog házasságba.

Úgy tünik, az Erótika pathémata modellszerepe nem csupán az Aeneis ezen helyén feltételezhető. A VIII. ének Cacus-epizódja (185-275), túl az állatrablás, a hátramenetben vezetett csorda nyilvánvaló homérosi párhuzamán, részben ugyancsak egy partheniosi elbeszélés Kontrastimitation vezérelte újrafogalmazásának tekinthető. A vergiliusi Hercules Nyugatról tér vissza Géryóntól rabolt csordájával. A hőst Itáliában Cacus tartóztatja fel útján, aki elrabolja s egy barlangba zárja az állatokat - hogy visszaszerezze őket, a hérósnak le kell ereszkednie a föld mélyébe s ott megvívnia a chthonikus szörnyeteggel. Hasonló, aitiológiai mozzanattal bővülő történet szerepel Parthenios

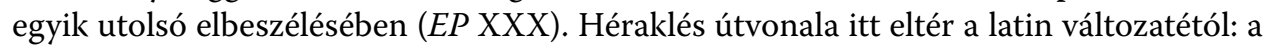
hős teheneivel Észak felé indul, ahol Bretannos király leánya, a szép Keltiné lopja s rejti el az állatokat. Hogy újra birtokukba jusson, Héraklésnek szerelmi élvezetekben kell részesítenie az előkelő tolvajt: az együttlétre a homérizáló $\mu \nmid \chi \theta \tilde{\eta} v \alpha \imath$ alak utal. ${ }^{51}$ Míg a görög történetben a testek vegyülése erotikus egybefonódást jelent, amelynek eredménye Keltinos, a kelták héros epónymosának születése, a $\mu \imath \theta \tilde{\eta} v \alpha \imath$ Vergiliusnál kozmikus

${ }^{49}$ Cf. NA IX, 9, 3 (= T 9c Lightfoot): Vergilius cum aut Homeri, aut Hesiodi aut Apollonii aut Parthenii aut Callimachi aut Theocriti aut quorundam alios locos effingeret, partim reliquit, alia expressit.

50 W. Clausen: Virgil and Parthenius. HSCPh 80 (1976) 179.

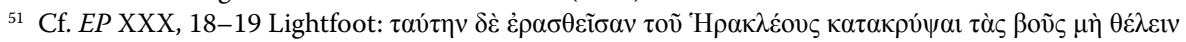

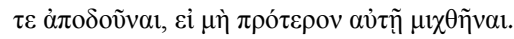


erők alvilági harcaként valósul meg. ${ }^{52}$ Parthenios neve nem szerepel a vergiliusi epizód lehetséges forrásai között..$^{53}$

A fentiekben utaltunk már a partheniosi, prózai mítoszgyüjteménye (illetve a szerző elveszett Metamorphósisa) és a VI. ecloga párhuzamaira. Az Erótika pathémata és a Georgica mitológiai allúziói közötti esetleges megfelelések, tudatos analógiák és kontrasztok sokkal kevésbé ismertek. A tanköltemény mítoszkezelése és szerelemfelfogása kapcsán az olvasatok szinte kizárólag a IV. éneket záró, hellénisztikus ihletésü Orpheus-epyllionra koncentrálnak, s ha távoli párhuzamaként említik is annak tragikus hangneme kapcsán az Erótika pathématát, ${ }^{54}$ azt részletekbe menő vizsgálat nélkül teszik. Ennek ellenére úgy tűnik, hogy az Orpheus-mítoszon és az állatok nemiségét alaptémaként tárgyaló III. könyvön túl a mezőgazdaságnak s tágabban ember és természet kapcsolatának szentelt alkotás mélyszerkezetében több helyütt fellelni a vággyal, a szenvedély megélésével s azok etikai viszonylataival kapcsolatos helyeket. ${ }^{55}$ A vergiliusi természeti képek, a tanköltemény növény- és állatábrázolásainak többsége elliptikus eredetmítosz, amelyekben a cselekmény legfőbb motiválója a szerelmi vágy. A mü ezen erotikus olvasatának lehetősége megerősítést nyer Servius által, akinek kommentárja szinte minden esetben az istenek és a halandók aitionként funkcionáló szerelmi történeteire vezeti vissza az egyes, zoológiai, botanikai adatokat közlő helyeket. A Georgica tájait egykoron emberi formában létezett lények népesítik be, akik fává, csillaggá, sziklává változnak, vagy állati testbe záratnak a földi szenvedésüket megszánó istenek kegyelme vagy a féltékeny égiek könyörtelensége révén. Az egyes élőlények kapcsán elhangzó, aitiológiai természetű mitológai allúziók elsődleges szerepe a cselekvő embert (az arator meglehetősen halvány és személytelen alakján túl) nem ábrázoló, emiatt a kozmosz befejezetlenségének érzetét keltő mű világképének humanizálása lenne. Az Orpheus és Eurydiké történetében kiteljesedő, ezáltal a mű főszólamába átkerülő mítosztöredékek sorozata ezáltal a költemény másodlagos, a négy könyv fötémáinak hátterében maradó, azoknál kevésbé szembetűnő narratív vázát is létrehozza.

52 Vergiliusnál a vegyülés a harc külső körülményeire vonatkozik (cf. Aen.VIII, 255: noctem commixtis igne tenebris), az erotikus felhang azonban megmutatkozik a szóválasztásban: ibid. 260: (...) corripit in nodum complexis.

${ }^{53}$ Lásd pl. K. G. Galinsky: The Hercules-Cacus Episode in Aeneid VIII. TAPhA 87 (1966) 18 skk., illetve D. Sutton: The Greek Origins of the Cacus Myth. CQ 27 (1977) 391 skk. Az epizódban erotikus innuendo jelenlétét feltételező M. C. J. Putnam: Virgil's Aeneid: Interpretation and Influence. Chapel Hill - London 1995. 31 sk. sem utal Partheniosra.

54 Vö. L. P. Wilkinson: The Georgics of Virgil: A Critical Survey. Cambridge 1969. 184; Thomas: i. m. (31. jegyz.) I 15, 41. jegyzet; Morgan: i. m. (48. jegyz.) 162 skk., 169.

55 Vö. E. Pataki: Metamorphoses, amours et abeilles. Notes sur le livre IV des Géorgiques. AAntHung 44 (2004) 263 skk. 
4.

A Georgica és az Erótika pathémata közötti esetleges tematikai rokonságot a teljesség igénye nélkül keresve lássunk immáron néhány jellegzetes szöveghelyet! A mezei munkákat évszakonkénti megoszlásban tárgyaló földművesnaptárban az esős időszak érkeztét előrejelző madarakról olvasni (I, 406-409). A hely a Vergilius utáni költészetben igen népszerü, ${ }^{56}$ a szerelem romboló erejét illusztráló mítoszt, Nisus és Scylla történetét idézi. A hazájára támadó ellenségbe beleszerető hercegnő őrült szenvedélyében kiszolgáltatja apját az imádott ellenfélnek, aki azonban megvetéssel utasítja vissza a lányt. Részletező előadásra nincs szükség, a Georgica közönsége szemlátomást jól ismeri a (VI. ecloga Silenos-dalában és a pseudo-vergiliusi Cirisben is megidézett) történetet: ${ }^{57}$ a tanköltemény olvasója nem lát mást, mint az ornitológiai képet, a madárrá változott, kölcsönös gyülöletüket e formában is őrző apát és lányt. Nisus és Scylla története nem olvasható az Erótika pathémata gyüjteményében, de feltételezhető, hogy Parthenios másutt, bizonytalan müfajú metamorphósis-sorozatában feldolgozta azt. ${ }^{58}$ Nyilvánvaló, hogy a kettős átváltozásmítoszt evokáló vergiliusi hely nem eredeztethető közvetlenül Partheniostól (noha a kutatásban elvétve ennek gyanúja is megjelenik). ${ }^{59}$ Ennek ellenére a hazáját fenyegető ellenséges vezérbe beleszerető, a kizárólag a hadisikerben érdekelt hódító által azonban rútul becsapott királylány történettípusa számos alkalommal megjelenik a görög gyűjteményben, olykor rövid tematikus szekvenciát képezve. ${ }^{60}$ Így történik ez a XXI-XXII. fejezetekben is, amelyek cselekménye lényegében azonos: a királyi házból származó szerelmes lány elárulja családját az országukra törő idegen kedvéért, majd, csalódván annak álságos közeledésében, megalázottként hal meg, hol övéi boszszúja által, hol a színlelt szerető keze által sújtva. Noha Parthenios ezen alkalmakkor is tartózkodik az erkölcsi minősítés megfogalmazásától, úgy tűnik, a szerelemből árulóvá lett királylányokra lesújtó halál (akár az elárult család, akár az árulásból hasznot húzó

56 Servius csupán a Bucolica (VI, 74) kapcsán említi a mítoszt: Scylla fuit Nisi, Megarensium regis, filia. contra quos dum, devictis iam Atheniensibus, pugnaret Minos propter filii Androgei interitum, quem Athenienses et Megarenses dolo necaverant, adamatus a Scylla est, Nisi filia, quae ut hosti posset placere, comam purpuream parenti abscisam ei obtulit, quam Nisus ita habuerat consecratam, ut tamdiu regno potiretur, quamdiu illam habuisset intactam. postea et Scylla, a Minoe contempta, vel dolore, quod contempta esset, vel (quod) quasi parricida a Minoe ad puppim religata tracta sit, in avem Cirim conversa est, et Nisus extinctus deorum miseratione in avis mutatus est formam: quae aves hodie, ut ipse in georgicis docet, flagrant inter se magna discordia.

57 A madárrá változott Scylla mellett Vergilius ismeri az azonos nevű tengeri szörnyet is, utóbbi kizárólag az Aeneisben szerepel, vö. O’Hara: i. m. (19. jegyz.) 94 sk. A mitológiai homonímián alapuló szójátékokról lásd N. Horsfall: Virgil, Parthenius and the Art of Mythological Reference. Vergilius 37 (1991) 31 skk., főként 35.

${ }^{58}$ Cf. fr. 24 Lightfoot, a részleteket lásd Lightfoot: i. m. (18. jegyz.) 164 skk.; Francese: i. m. (21. jegyz.) 10, illetve Harrison: i. m. (20. jegyz.) 48.

59 Vö. M. Gale: Virgil on the Nature of Things. The Georgics, Lucretius and the Didactic Tradition. Cambridge 2000. 128, 38. jegyzet (részletes indoklás nélkül).

${ }^{60}$ A részleteket lásd Lightfoot: i. m. (18. jegyz.) 496 skk. 
ellenség közreműködésével) a szerző együttérzéstől mentes elbeszélésében már-már jogos büntetésnek tünik, amely a közösség iránti lojalitás megszakítását ítéli el s torolja meg. (A szenvtelenség mindazonáltal a sietős előadás velejárója is lehet.) A civil becsület elvesztését az elkövető női mivolta ráadásul súlyosbítani látszik: a győztes és a legyőzött férfiak egyaránt elutasítják a tisztességtelen eszközök nő részéről történő használatát. ${ }^{61}$

Az ellenségbe szerelmes, becsapott királylány történettípusának jó példája a gyűjtemény XXI. darabjaként olvasható, lesbosi hagyományon alapuló s az epikus mondakör egy kevéssé ismert mozzanatát idéző elbeszélés, amelynek Apollónios Rhodios-féle feldolgozását hosszasan idézi Parthenios. A homérizáló nyelven megszólaló vázlatos történet főszereplője Achilleus, aki nem tartja be az őt imádó, beszélő nevével is a naiv fiatal lány karakterét megtestesítő Peisidikének tett esküjét, ${ }^{62} \mathrm{~s}$ ahelyett, hogy a várat a kezére játszó lányt feleségül venné, katonáival kövezteti őt halálra. A következő elbeszélés (EP XXII) Sardeis ostroma idején játszódik, amikor is Kyros hasonlóképp megszegi az őt imádó Nanisnak, Kroisos lányának tett fogadalmát, noha a lány, a perzsa szokások erejében bízva (ti. hogy majd a hódító feleségül veszi) a falak egy őrizetlenül hagyott pontján az erődbe vezeti az ellenséges csapatokat. Az események végkifejletéről, Nanis későbbi sorsáról Parthenios nem beszél. Kizárólag az esküszegés tényére utaló, nyitott végű elbeszélésével a történet lekerekítését, a lehetséges befejezésvariánsok közötti választás lehetőségét az (azt esetleg majd újraíró) aktuális olvasóra hagyja.

A szenvedély elragadta lány megszégyenítő, erőszakos halálával végződő történet csupán egyik alfaja a szerelmi árulás elbeszéléstípusának, amely más esetben a tragikus zárás ellenére is szelídebb végkifejletbe torkoll, néhol pedig teljesen pozitív befejezést kap. Előbbire példa a Naxos és Milétos konfliktusának idején játszódó Polykrité-elbeszélésben olvasható ( $E P$ IX). E változatban az ellenséges sereg vezére gyúl izzó szenvedélyre az ostromlott várban lakó szép és bátor lány iránt, aki a helyzetet hazája megmentésére használja fel, s átállásra biztatja imádóját. A győztes naxosiak az ellenség elűzése utáni napon ünnepelni szeretnék a lányt, aki azonban a honfitársai által hálából ráaggatott tiarák, díszruhák súlya alatt - hazáját megmentő, fordított Tarpeiaként - életét veszti. A Parthenios-kutatás természetesen ismeri a szerelmi szenvedély hatására elkövetett politikai árulás történetsémáját, $\mathrm{s}$ azt mindenekelőtt a római történelem imént említett, Livius, Propertius s mások megörökítette emblematikus női árulója kapcsán vizsgálja. ${ }^{63}$ A fentiek fényében a vergiliusi Scylla-allúzió ugyancsak ezen, Rómába talán Parthenius által bevezetett elbeszéléstípus rokona lenne.

Szintén az idegent imádó királylány történetsémája fedezhető fel a Georgica elejének egy további, csillagászati-meteorológiai vonatkozásban szereplő utalásában (I, 222):

${ }^{61}$ Hasonló, a házasságtörő asszonyi elvetemültség láttán elborzadó s egymásnak békejobbot nyújtó megcsalt görög férj és barbár (!) csábító története olvasható Parthenios VIII. elbeszélésében.

${ }^{62}$ A partheniosi személynevekben megmutatkozó etimologizáló tendenciáról, szójátékokról, a névadás iróniájáról lásd O’Hara: i. m. (19. jegyz.) 44, illetve Billault: i. m. (37. jegyz.) 25.

${ }^{63}$ A Scylla-történet pseudo-vergiliusi és ovidiusi változatairól, illetve a latin elegikusok Tarpeia-történeteiről lásd főként E. Delbey: Aimer son ennemi(e). In: Zucker: i. m. (23. jegyz.) 175 skk., lásd még Francese: i. m. (21. jegyz.) $157 \mathrm{skk}$. 
Cnosiaque ardentis decedat stella Coronae. A sor Ariadné mítoszát idézi: a távolról, ellenséges szándékkal érkezett Théseus bűvöletében a krétai királylány megkönnyíti féltestvére legyilkolását, később azonban a hazafelé igyekvő athéni aljas módon megszabadul az érte mindent otthagyó, szerelmes lánytól. Servius szerint az öngyilkosság határán álló Ariadnét Dionysos menti meg, s emeli az égbe isteni nászra, amint erről a csillagképpé változott menyasszonyi öv tanúskodik. ${ }^{64} \mathrm{~A}$ krétai mítosz túlságosan ismert ahhoz, hogy Parthenios felvegye gyüjteményébe, központi narratívája azonban rokonítható az irracionális női szenvedélyt politikai célokból kihasználó férfiúi aljasság fentebb említett történeteivel. A vergiliusi Ariadné-utalás újdonsága egyrészt a női nézőpont kizárólagosságában rejlik, ${ }^{65}$ másodsorban a hellénizmus aitiológiai költészetében gyakori katasterismos motívumának megjelenésében, amely az Erótika pathématában egyetlen alkalommal sem fordul elö, s amelyre Catullus 64. carmenében sincs utalás. ${ }^{66}$ Megemlítendő a történet szerencsés végkimenetelét biztosító isteni közbeavatkozás is, amelynek révén a halandó férfi által megvetett Ariadné az Olymposon talál hitvesi boldogságra. A női ruhadarab átváltozásának középpontba állításával a latin költő a mítosznak a labirintusban vezető fonalnál vagy a Naxoson magára hagyott lány panaszánál kevésbé ismert részletére összpontosít. Az elfeledett vagy ritkán tárgyalt mitológiai mozzanatok kiemelésének szándéka részint a Georgica III. énekének prológusában hangoztatott elveknek felel meg: az avítt témák szüntelen ismétlésének elutasításával Vergilius valami újat, az ilyesmire ráérő hallgatóság figyelmét lekötni képes elbeszélést keres (cf. III, 3: cetera, quae vacuas tenuissent carmine mentes).$^{67}$ Az Ariadné-utalás másrészt hasonlóságot mutat az eleddig nem tudott vagy nem vállalt kimondásának esztétikumával, amely az Erótika pathémata általános jellemzőjének tekinthető, s amely Partheniosnál többnyire a mitikus elbeszélés hátterében meghúzódó sötét, zavaros, titkolt mozzanat elbeszélését jelenti. A kevéssé ismert momentumként az átváltozást, az Ariadné-történet e fényes oldalát megjelenítő, a megdicsőülő hősnőt égbe emelő, az isteni elégtétel motívumán alapuló latin allúzió e szempontból ellentétje a partheniosi elbeszélések megtorlás nélkül maradt bűnökkel terhes világképének, gyakorta félelmet keltő atmoszférájának.

Az isteni gondoskodás Ariadné-utalásban felsejlő gondolata a Georgica I. énekének egy későbbi helyén is megjelenik, a tengeristennő által pártfogolt jégmadarak eredetmítoszának felidézésekor (I, 398): Dilectae Thetidi alcyones. A Servius által is közvetített aition szerint Ceyx és Alcyone házastársi hüségükkel nyerik el Thetis bi-

${ }^{64}$ Lásd Serv. ad Georg. I, 222: Theseus cum ad interimendum Minotaurum Cretam venisset, miseratam eius Ariadnen auxilium ei ad occidendum, filo ducto, Minotaurum praestitisse; Theseum vero Ariadnen, utpote salutis auctorem, secum avexisse, qui cum ad Naxum insulam delati essent, Ariadnen ibi vel consulto vel necessitate vel monitu Mercurii a Theseo derelictam. quam cum Liber pater adamasset, coronam ei dempto pudore, sicut supra dictum est, dicitur obtulisse: quam etiam inter sidera postea conlocavit.

${ }_{65}$ Ariadné másutt nem szerepel Vergiliusnál. A Georgica Théseust az athéni színház kontextusában (II, 383), az Aeneis az alvilágjárás kapcsán említi (VI, 122, 393, 618).

66 A csillaggá változás a név Apollónios Rhodiosnál megjelenő etimológiájával (fényes, ragyogó) is öszszefügghet, vö. O’Hara: i. m. (19. jegyz.) 29, 125. jegyzet.

${ }^{67}$ A vitatott jelentésü vacuas mentes kapcsán lásd pl. M. J. C. Putnam: Italian Virgil and the Idea of Rome. In: Vergil's Georgics. Ed. K. Volk. Oxford 2008. 146 sk. 
zalmát. ${ }^{68}$ Parthenios nem említi a párt, azonban a házasság keretei között megélt boldog, majd tragédiába forduló szerelem narratív sémája (az átváltozás motívuma nélkül) megjelenik a gyüjteményben, mindenekelőtt az annak utolsó elbeszélését képező Rhésus-mítoszban (EP XXXVI), amelyet a vergiliusi tanköltemény szintén említ (IV, 462, lásd később).

A jégmadarakhoz visszatérve: a házaspár nőtagjának vergiliusi neve sajátos rokonságot mutat (s ezáltal a latin költőre olyannyira jellemző szójátékot képez) Parthenios egy hősnőjének nevével. Az Erótika pathémata XXVII. fejezetében az olvasó egy bizonyos Alkynoé történetével ismerkedik meg, ${ }^{69}$ aki a vergiliusi $(\mathrm{H})$ alcyonétól jelentősen eltérő jellemvonásokat mutat. A görög elbeszélés férjes asszonya fizetség nélkül űzi el házából egyik becsületes szolgálóját, s ezzel magára haragítja a mesterségek istennőjét. Athéné sajátos bosszút eszel ki megleckéztetésére: Alkynoé egy tengerentúlról érkező idegen iránt gyúl olthatatlan szerelemre, s megszökik vele, azonban a hajóút közepén lelkiismeret-furdalás tör rá, $\mathrm{s}$ az immár kétszeresen bűnös asszony a tengerbe veti magát (tette a katapontismos purifikációs rítusát idézi). A korábban elkövetett, nem feltétlenül érzelmi természetű jogtalanságot megtorló, büntetés gyanánt lesújtó szerelem képzete másutt is szerepel a görög sorozatban (lásd a később tárgyalandó Niobé-változatot, $E P$ XXXIII), azonban ismeretlen Vergiliusnál.

A növénytermesztéssel foglalkozó II. énekben viszonylag kevés mitológiai allúzió szerepel. Az egyetlen valódi eredetmítosz, amelynek megjelenése a szerző tudatos poétikai szándékára vezethető vissza, ${ }^{70}$ a szöveg elején olvasható parnasia laurus / parva sub ingenti matris se subicit umbra (18-19) sorokban valószínűsíthető. A babér képe a fák családjait tárgyaló rövid botanikai katalógusba illeszkedik. A lista első része a földbe ültetett magból szaporodó növényeket veszi sorra, a megszemélyesítésen alapuló folytatás azokat, amelyek a talajba bujtatott anyai hajtásból szökkennek szárba. ${ }^{71}$ A parnasia melléknév kétségkívül Apollón Daphné iránti heves vágyára utal, akinek fává változását - ritka átváltozástörténeteinek egyikeként - Parthenios önálló elbeszélésben tárgyalja $(E P X V)$. Az antik szövegmagyarázók közvetlen kölcsönzés feltételezése nélkül a babér (a Bucolicában szintén megjelenő) vergiliusi képét párhuzamba állítják a partheniosi elbeszéléssel. ${ }^{72}$ A görög eredetmítosz mindazonáltal jelentősen eltér az ovidiusi Meta-

${ }^{68}$ Serv. ad Georg. I, 399: Ceyx, filius Luciferi, habuit uxorem Alcyonen. a qua cum prohibitus isset ad consulendum Apollinem de statu regni sui, naufragio periit. cuius corpus cum ad uxorem delatum fuisset, illa se praecipitavit in pelagus. postea miseratione Thetidis et Luciferi conversi sunt ambo in aves marinas, quae alcyones vocantur (...).

${ }^{69}$ A részleteket lásd Lightfoot: i. m. (18. jegyz.) 520 skk.

${ }^{70}$ Servius viszont üldözéstörténeten alapuló szerelmi mítoszra utal a lótuszfa kapcsán is (II, 84): Lotos nympha quaedam fuit, quam cum amatam Priapus persequeretur, illa deorum miseratione in arborem versa est (...).

${ }^{71}$ Lásd Ch. Nappa: Reading after Actium. Vergil's Georgics, Octavian, and Rome. Ann Arbor 2005. 71.

72 Cf. Probus, Comm. ad Ecl. III, 62: Laurus Phoebo grata, quod Daphnen ut vult Parthenius in volumine quod ei de amantibus compositum est. Servius a babér esetében meglepő módon nem hoz erotikus aitiont (ad II, 18): A Parnaso monte Apollini consecrato. Cadili: i. m. (32. jegyz.) 182, 62. jegyzet a Georgica babérja kapcsán részletes érvelés nélkül utal Partheniosra. Harrison: i. m. (20. jegyz.) 58 a partheniosi Metamorphoses modellszerepéről ír. 
morphoses nyomán általánosan ismert verziótól. Parthenios két elbeszélést keresztez: egy szerelmes fiatalember női ruhát ölt magára, hogy így férkőzhessék Artemis szép társnője, a szűz Daphné közelébe. Csalását a lány után szintén vágyakozó, az Erótika pathématában sehol másutt nem szereplő Apollón leplezi le, mégpedig jellegzetes, a ruhaváltás/nemváltás témáján alapuló mítoszok elengedhetetlen részét képező fürdésjelenetben. Az isten halállal bünteti földi vetélytársát, majd vágya tárgyának üldözésébe kezd, sikertelenül: Daphné Zeus kegyelméből fává változik. ${ }^{73}$ Az elbeszélés egyedülálló Parthenios gyűjteményében, ahol a halandók és istenek közötti szerelmi viszony ábrázolására ez az egyetlen példa, szemben a Georgica szerelmi utalásaival, amelyeknek döntő többsége ilyesfajta, a létszférák átjárhatóságán alapuló történetre céloz.

A mítoszfragmentumot felvillantó vergiliusi növényleírás nem bontja ki a Daphnétörténetet, mi több, tudatosan kerülni látszik bármiféle erotikus konnotációt. Szemben a későbbi, ovidiusi változattal, amelyben fontos szerep jut Daphné (Kallimachosreminiszcencia keretében ábrázolt) folyóisten apjának; ${ }^{74}$ Vergilius a rejtekadó, a bajba jutott kicsi lánynak ( $p a r v a$ ) védelmet nyújtó lombok képét az anyai gondoskodás összefüggésében jeleníti meg (II, 19: sub ingenti matris [...] umbra). Az önuralmát elvesztő, s ezáltal a Parthenios-elbeszélés vágytól, haragtól és gyűlölettől izzó istenéhez hasonló Apollón alakjának mellőzése a latin költeményben tudatos döntés eredményének tekinthető. ${ }^{75}$

Az isten neve nyíltan mindössze kétszer hangzik el a Georgicában, mindkét esetben az utolsó énekben. Elsőnek az invocatio keretében (IV, 6-7), amelynek során a költő a tárgy aprólékos kidolgozásával (in tenui labor) és a segítségül hívott Apollón jóindulatú támogatásával (auditque vocatus Apollon) elnyerhető, nem kis dicsőségről (tenuis non gloria) beszél. A isten neve a könyv végén, Aristaeus monológjában, figyelemre méltó mise en abyme keretében tér vissza (IV, 323: Thymbraeus Apollon): Apollón és Kyréné fia ugyancsak egy nimfát üldöz vágyával - Eurydikének azonban, szemben Daphnéval, nem adatik meg, hogy átváltozás árán megmeneküljön az erőszakos közeledéstől. Az utóbbi évek kutatásai szerint Apollón képe Augustus hatalomra jutásának éveiben jelentős változáson megy át: a császárkort megelőző időszak irodalmának kisebb jelentőségű istene a rend, az összhang, a kiegyensúlyozottság fenséges patrónusává válik. ${ }^{76}$ A szenvedélyeknek ellenállni nem képes (majdan Ovidiusnál látott) Apollón portréja bizonyára kínosan érintené az önmagát a harmónia fenséges istenével nyíltan azonosító, új erkölcsi rend létrehozását szorgalmazó uralkodót.

Apollón elliptikus alakja megjelenik azonban a főtémaként az állattenyésztéssel foglalkozó III. énekben is, mégpedig a praeteritio retorikai eszközére épülő előhangban.

73 A fává változó lányok általános toposza, illetve a Daphné-történet kapcsán lásd P. M. C. Forbes Irving: Metamorphosis in Greek Myths. Oxford 1990. 261 skk.

${ }^{74}$ Cf. Met. I, 481-489, 545, az isteni apa és a tőle szüzessége megtartásának lehetőségét kérő lány kettőse az Artemis-himnusz bevezetőjének újraírása.

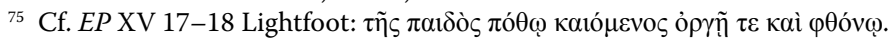

${ }^{76}$ Vö. J. F. Miller: Apollo, Augustus, and the Poets. Cambridge 2009. 344 skk. 
Unalomig ismert régi történetek (III, 4: omnia vulgata) helyett a költő e helyütt kortárs téma mellett dönt, az Augustus Caesarnak szentelt majdani templum képét vázolva. A gondoskodó, a növekvő lények fejlődését, kiteljesedését biztosító atyai Apollón képe a különleges, még nem létező mütárgyat leíró ekphrasis 36. sorában tünik fel, amely kultuszhelyet nevez meg az isten epithetonjaként: Troiae Cynthius auctor. A par excellence augustus uralkodó környezetében megjelenő növekedés-képzet a II. ének anyja árnyékában megbúvó, a nyíltan meg nem nevezett fenyegetésekkel szemben oltalmat ott találó fiatal babérfáját/babérlányát is idézheti, akinek a pillanat erejéig felidézett eredetmítosz-töredéke pontosan Apollón erőszakos, pusztító aspektusát helyezi előtérbe.

Ami az ezerszer újramesélt, divatjamúlt görög mítoszokkal szemben választott, még nem létező szakrális építmény narratív szerepét illeti, a kutatás joggal emeli ki a képzeletbeli monumentum leírásának megkérdőjelezhetetlen metaletterális funkcióját. Csupán két példa: Thomas olvasata az épület vergiliusi bemutatását az olympiai Zeustemplom Augustus parancsára végzett rekonstrukciós munkálataival állítja párhuzamba: a Georgica virtuális temploma ezen archaikus görög modell kortárs latin imitatiójának tekinthető. ${ }^{77}$ Nappa interpretációja a költői halhatatlanság gondolatának megjelenésén túl $^{78}$ a Hercules-mítosz erőteljes jelenlétére hívja fel a figyelmet a mellőzött mítoszokban, s Octavianus héraklési portréját véli felfedezni a sorok mögött - a civilizációs hérós Parthenios ismeretlen müfajú, elveszett Héraklésének központi alakjaként is jelen lehetett a korszak latin irodalmában, s mint elhangzott, ugyancsak szerepel (sem nem közismert, sem nem heroikus) Héraklés-történet az Erótika pathémata lapjain is. ${ }^{79}$

A III. ének prológusában elutasított témák között Vergilius utal két, túl sokszor újramesélt, s így poétikai vonzerejét vesztett szerelmi elbeszélésre is (III, 6-7): cui non dictus Hylas / Hippodameque umeroque Pelops insignis eburno? A Hylas-történethez és az olympiai versenyjátékok eredetmítoszához hasonló eseménysorok az Erótika pathématában is fellelhetőek. Ami a VI. ecloga Silenos-dalában is említett nympholéptos Hylast illeti, Héraklés ifjú védencének eltünése, a belé szerelmes forrásnimfák általi elrablása (azaz földi fogalmak szerinti halála) nem szerepel Parthenios prózai vázlatai között; a költő a témát bizonyára más müfajban, elveszett Metamorphosisában dolgozta fel. ${ }^{80} \mathrm{Az}$ Erótika pathémata elbeszélései között mindazonáltal helyet kapott egy olyan szerelmi történet, amely ugyancsak a víz mélyén, mintegy véletlen baleset során életét vesztő szépséges ifjú alakja köré épül (EP XIV). Parthenios Alexandros Aitólos költeményét követő, erre vonatkozó forráshivatkozást is tartalmazó elbeszélése a Hylas-mítosz szekularizált változatát kínálja. A civilizált, városi környezetbe átültetett elbeszélés szerint Milétos királynője szeretné elcsábítani az udvarukban politikai túszként tartózkodó

77 Vö. Thomas: i. m. (15. jegyz.) 44 skk.

${ }^{78}$ Nappa: i. m. (71. jegyz.) 116 sk. Ennius-helyek reminiszcenciájára hívja fel a figyelmet, amelyek révén a szöveg az olvasót az immár halhatatlan ősi költő s az öröklétre még csupán törekvő Vergilius közötti párhuzam megfogalmazására készteti.

${ }^{79}$ Vö. Harrison: i. m. (20. jegyz.) 151, a kutató az EP XXX. fejezetére nem utal.

${ }^{80}$ Vö. fr. 32. Lightfoot, lásd még Harrison: i. m. (20. jegyz.) 51. 
fiatal, nemes származású és erkölcsös Antheust. (A név önmagában is figyelmet érdemel, hiszen azonos nevü férfialak megjelenik az Aeneisben is, $\mathrm{s}$ a föhős szövetségeseként bemutatott ottani Antheus első említése [I, 181] ugyancsak a vízben való eltűnés motívumához kapcsolódik: a Karthagóban partot ért Aeneas a tengert kémleli, hátha megpillantja valahol a vízen iactatum vento férfit.) Az ifjú visszautasítja az asszony közeledését - a történet ennyiben a Phaidra-mítosz alapképletét és a Partheniosnál már többször látott, az ellenség iránt érzett szerelem narratív toposzát vegyíti. A vérig sértett, kijózanodást színlelő, de valójában bosszút forraló nő arra kéri az ifjút, ereszkedjék le egy kút mélyére, s hozza fel onnan vízbe esett, szelídített fogolymadarát. ${ }^{81}$ Amint Antheus leér a kút aljára, a királynő hatalmas követ gördít föléje, s az halálra zúzza az ifjút. A Hylas-mítosz közvetett jelenléte az elbeszélés hátterének egy látszólag jelentéktelen mozzanatával igazolható: a történet Aitólostól hosszasan idézett verses változatában a mélyből felhozandó tárgy a madár helyett egy aranyból készült korsó lenne: ${ }^{82}$ a merítőedény motívuma az Argonauta-elbeszélés jól ismert, a hellénisztikus költők (s később a császárkori képzőművészet ${ }^{83}$ ) által oly sokszor feldolgozott forrás melletti jelenetét idézheti. A gyilkos szerelem története Partheniosnál a bűnbánat motívumával zárul: a kegyetlen bosszúja ellenére szenvedélyétől szabadulni képtelen királynő öngyilkos lesz, míg a történtekben vétlen királyi férj a vendégjog szégyenletes megsértése miatt lemond trónjáról.

A III. ének előszavának másik, szintén mellőzendőnek ítélt elbeszélése a csalás árán célt érő szerelem motívumára épül: cui non dictus (...) Hippodameque umeroque Pelops insignis eburno? A Servius által is hagyományozott, általánosan ismert földrajzi aition szerint Pelops és Hippodameia házasságkötését gyilkos színjáték segíti, ${ }^{84}$ amelynek során (az iménti, partheniosi Antheus-elbeszéléshez hasonlóan) az elkövetők emberölést próbálnak balesetnek álcázni. Hippodameia kérőinek kocsiversenyben kell megmérkőzniük a lány apjával. Az érte versengő Pelopsba beleszerető királylány megvesztegeti Oinomaos kocsisát, Myrtilost, s neki ígérve ártatlanságát arra kéri, szántszándékkal veszítse el a futamot, így juttatva első helyhez Pelopsot. A győzelem után az ifjú pár nem tartja szavát, s az urával szemben árulóvá lett kocsist egy szikláról a tengerbe vetik.

A fentihez igen hasonló, az ellenség iránti szerelem és a sportverseny motívumát egybefonó történet olvasható a partheniosi gyüjtemény VI. elbeszélésvázlatában.

${ }^{81}$ Megjegyzendő, hogy a perdix az ókori etológiában negatív konnotációval bír a féktelen nemi késztetésükön úrrá lenni nem képes hímek miatt, vö. Arist. HA 613-614a, Plin. NH X, 33, Ail. NA III, 5, 16.

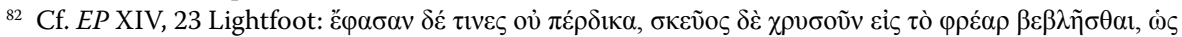

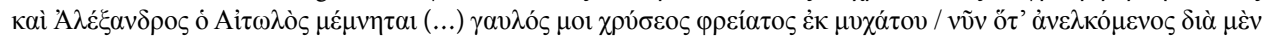

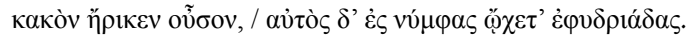

${ }^{83}$ Harrison: i.m. (20. jegyz.) 151 Apollónios Rhodios, Varro Atacinus, Theokritos hatására hivatkozik, az Erótika pathémata említése nélkül. A mítosz ikonográfiai vonatkozásairól lásd J. Lancha: L’iconographie d'Hylas dans les mosaïques romaine. CIMA III/2, Ravenna (1984) 381 skk.

${ }^{84}$ Cf. Serv. ad Georg. III, 7: (...) postea cum Pelopem amasset Hippodamia, corrupit Myrtilum, aurigam patris, primi coitus pactio, qui factis cereis axibus cum victore Pelope a puella promissum posceret praemium, ab eius mari praecipitatus in mare est, cui nomen imposuit. 
A szép thrákiai királylány, Palléné kezéért ketten versengenek, akik ez esetben is kocsiversenyben mérik össze erejüket. Palléné beleszeret az egyik jelöltbe, s dajkája közvetítésével megvesztegeti az ellenfél kocsisát, hogy az ura balesetnek álcázott meggyilkolásával segítse elő a lány szerelmével kitüntetett kérő győzelmét. Mielőtt azonban erre sor kerülne, a király, országa bölcs és igazságos uralkodója, tudomást szerez a cselről, s máglyahalálra ítéli Pallénét, akit viszont istenítélet ment meg a pusztulástól, a lángokat kioltó eső formájában. Noha a két elbeszélés számos eleme eltér egymástól, ${ }^{85}$ Palléné partheniosi története és Hippodameia alakjának felvillanása Vergiliusnál hasonló narratív alapszerkezetre megy vissza. Figyelmet érdemel továbbá, hogy a Pallene alak helynévként megjelenik a Georgica utolsó énekében is: a Chalkidiké félszigetén fekvő város a mindentudó tengeri öreg, az Orpheus-történetben kulcsfontosságú szerepet játszó Próteus szülőhelye. ${ }^{86}$

Ami a tanköltemény záróénekét illeti, a IV. könyv első, méhészettel kapcsolatos nagyobb egysége a kaptár természetes ellenségei között, aitiológiai utalás keretében szerepelteti a (VI. eclogában szintén megidézett ${ }^{87}$ ) fecskét (14): et manibus Procne pectus signata cruentis. A madarat említő rész szerkezeti és tartalmi fontosságát jelzi, hogy a fiókáit tápláló nőstény képe (17: ore ferunt dulcem nidis immitibus escam) az állati, ösztönös és a tudatos emberi cselekvés közti viszony kérdését veti fel, előkészítve ezáltal a méhkas életének humanizáló kifejezésekkel élő leírását. ${ }^{88} \mathrm{~A}$ fészekaljáról gondoskodó fecskeanya képét előtérbe helyező vergiliusi ornitológiai utalás emellett szembefordul a mítosz hagyományos karakterábrázolásával, amely mindenekelőtt a bántalmazott nővérével, Philomélával együttérző Prokné irtózatos bosszújára fókuszál: az anya a bántalmazóval közös gyermeke gyilkosává válik, s feltálalja a kis holttestet az apának. A hirundo képe ezen túl a IV. ének egészének szerkezeti felépítésében is fontos szerepet tölt be, hiszen keretet alkot a Georgica nagy mitológiai záróelbeszélésével: Orpheus gyászának ábrázolásában Vergilius a fecsketestvér csalogány fájdalmas dalát hallatja olvasóival (511-515: maerens philomela sub umbra).

Prokné és Philoméla története a görög mítosz legősibb rétegeihez tartozik, s mint ilyen, nem képezi részét a partheniosi gyüjteménynek. ${ }^{89}$ A gyermekgyilkosság emberevéssel kiegészülő motívuma (amely többnyire egy másik családon belüli bủntény, az incestus következménye) viszont megtalálható az Erótika pathémata lapjain is. A fel-

${ }^{85}$ Míg a vergiliusi Pelops-ábrázolás Pindaros első olympiai ódáját idézi, Partheniosnál a hérodotosi Kroisos-elbeszélés (I, 86) hatása fedezhető fel. A Palléné-történet kapcsán a részleteket lásd Lightfoot: i. m. (18. jegyz.) 403 skk. Harrison: i. m. (20. jegyz.) 152 a Pelops-említés kapcsán sem utal az Erótika pathémata esetleges hatására.

${ }^{86}$ Cf. Georg. IV, 390-391: hic nun Emathiae portus patriamque revisit / Pallenen (...).

${ }^{87}$ Harrison: i. m. (20. jegyz.) 56 sk. a bukolikus szövegben az elveszett partheniosi átváltozás-költemény hatását feltételezi.

${ }^{88}$ Vö. Nappa: i. m. (71. jegyz.) 163.

${ }^{89}$ Cf. Serv. ad Georg. IV, 14: nomen posuit pro nomine; nam Philomela in hirundinem versa est: pro qua Procnen vel quasi sororem posuit, vel quasi eam, quae fuerat illius sceleris causa; nam ipsa Tereum miserat ad adducendam sororem. 
tűnően kevés, mindössze három partheniosi átváltozástörténet egyike a $\chi \alpha \lambda \kappa i ́ \varsigma$ nevü madár eredetmítosza (EP XIII). Egy Harpalyké nevű fiatal lányt apja vérfertőző viszonyra kényszerít, majd a menyasszony visszarablásával meghiúsítja annak egy becsületes fiatalemberrel kötendő házasságát. (A kérő, Alastór beszélő nevet visel, amelynek révén alakja az isteni igazságszolgáltatás képviselőjeként - vagy még inkább ezen igazságszolgáltatás hiányának jelzéseként értelmezhető.) A szörnyű kapcsolatból menekvést jelentő házasság elmaradása miatt a szerencsétlen lány öccse meggyilkolásával áll bosszút, akinek testét feltálalja apja asztalán. A szenvedései megszüntéért könyörgő, az elszenvedett erőszak hatására gyilkossá vált áldozatot az istenek madárrá változtatják. A Vergilius és Parthenios közötti esetleges párhuzamok mindenekelőtt két ponton mutatkoznak. Elsőként a szóalakokkal folytatott játékban, amely a vergiliusi, szinte minden esetben motivált névadás közismert alapeleme. A görög Harpalyké összetett alak, amelynek első, igei része a ragadozásra, zsákmányolásra utal ( $\dot{\alpha} \rho \pi \alpha ́ \zeta \varepsilon \imath v)$, míg második felében a farkas jelentésű $\lambda$ úkoৎ nőnemű alakváltozata egyértelműsíthető. ${ }^{90}$ A női név Vergiliusnál fontos, a partheniosi elbeszéléstől merőben eltérő epizódban bukkan fel, az eposz karthagói színében. Parthenios elbeszélésében Harpalyké a vérfertőzés brutális aktusának ártatlan áldozata, aki környezete hatására morális torzuláson megy át, amelynek következtében az őt ért sérelemnél nem kevésbé szörnyü, erőszakos tettet hajt végre. Az Aeneis I. énekének Venus-epifániája során Harpalyce magától értetődő gesztussal öldöklő thrák vadásznőként jelenik meg az istennőt láttató hasonlatban. ${ }^{91}$ A latin Harpalyce ezen pusztító aspektusa áttételesen az eposz másik vad lányalakját is idézheti: Camilla aristeiájának katalógusában az áldozatok között olvasható egy bizonyos Harpalycus neve is (Aen. XI, 676). Megjegyzendő másrészt, hogy a partheniosi Harpalyké-történetet záró madárrá változás Vergiliusnál is az incestus-elbeszélések szokásos befejezése. ${ }^{92}$ (Utóbbira jó példa az I. ének végi, a bagoly nyugtalanító hangjának megszólaltatásával Nyctimenét idéző sor, aki ugyancsak apja vérfertőző vágyának áldozata. ${ }^{93}$ )

Orpheus, Eurydiké és Aristaios történetének, a tanköltemény egyetlen részletesen előadott szerelmi mítoszának elemzése nem feladatunk e helyütt. A lehetséges partheniosi párhuzamokkal kapcsolatban mindenesetre megjegyzendő, hogy bár a költő nem vádolja nyíltan Aristaiost nemi erőszakkal, Eurydiké első pillantásra tragikus balesetnek tűnő haláláért és közvetetten Orpheus pusztulásáért is Apollón fia a felelős - hason-

90 Vö. Forbes Irving: i. m. (73. jegyz.) 250 sk.

${ }^{91}$ Cf. Aen. I, 316-317: Cui mater media sese tulit obvia silva / virginis os habitumque gerens, et virginis arma / Spartanae, vel qualis equos Threissa fatigat / Harpalyce, volucremque fuga praevertitur Hebrum. - A névadás tudatosságát jelző O’Hara: i. m. (19. jegyz.) 53 csupán más, Harpax nevű szereplőket említ Harpalyce kapcsán.

92 A madárrá változó lányok toposzához Forbes Irving: i. m. (73. jegyz.) 115. A partheniosi Harpalyké-történet forrásairól Lightfoot: i. m. (18. jegyz.) 446 skk.; Cameron: i. m. (38. jegyz.) 108 sk., illetve Francese: i. m. (21. jegyz.) 137.

${ }_{93}$ Cf. Serv. ad Georg. IV, 403: Nyctimone postquam cum patre concubuit et agnovit facinus esse, in silvis se abdidit et lucem refugit, ubi deorum voluntate conversa est in avem, quae pro tanto facinore omnibus avibus est admirationi. 
ló, háromszereplős, kettős halállal (pontosabban a női áldozat átváltozásával) végződő szerelmi tragédiával Partheniosnál Daphné már említett történetében ( $E P$ XV) találkozni. Noha az Orpheuséhoz hasonló művészelbeszélés nem szerepel az esztétikum szféráját egyetlen esetben sem tematizáló görög gyüjteményben (nota bene, a partheniosi Daphné-történet Apollónja, Ovidiusétól eltérően, egyáltalán nem próbál szavaival, művészetével hatni kiszemelt áldozatára), a mitikus énekes gyászát s a vele együttérző természetet ábrázoló vergiliusi sorokban találni az Erótika pathématából ismerős helyzeteket, szereplőket. Az eltünt Eurydikét a nimfák karán túl a hegyek és a sziklák is siratják, $\mathrm{s}$ a halálesetet követő fájdalom univerzális mivoltát megjelenítő rövid földrajzi katalógus három szerelmi történetet is idéz, amelyek közül kettő motívumviláguk hasonlósága vagy a bennük említett szereplők névazonossága révén összefüggésbe hozható az Erótika pathémata egyes fejezeteivel. ${ }^{94}$

Rhodopé és férje, Haimos története az ovidiusi Arachné-elbeszélésben tér majd vissza hasonlóan rövid utalás formájában (Met. VI, 87-89), de a Vergiliusnál olvasható personificatio (461: flerunt Rhodopeiae arces) tükrében a Georgica költője is ismerhette a házaspár átváltozással végződő történetét. (A Metamorphoses szerint a boldogságtól megrészegült, halandó mivoltukat feledő szerelmesek Jupiternek s Júnónak szólítják egymást, heggyé változtatásuk e hybris büntetése.) Noha Rhodopét és Haimost nem említi sehol név szerint a partheniosi gyüjtemény, történetük egykori jelenléte a görög alkotó müveiben nem zárható ki. ${ }^{95}$

A túlságos boldogságáért bűnhődő pár történetét Rhésus említése követi a Georgica gyászjelenetében (462: Rhesi Mavortia tellus). ${ }^{96}$ A mondat a Mavortia jelző militáris felhangja miatt leginkább a férfi Trója alatti meggyilkolásának a homérosi tradícióból is jól ismert epizódját idézi. Mindazonáltal nem zárható ki, hogy Vergilius egyúttal Rhésus és hitvese egykori, boldog szerelmére is utal, hiszen pontosan ez az érzelmi állapot teszi alkalmassá Rhésus országát a halott Eurydikét sirató Orpheus iránti részvétre. Rhésus és Arganthonoé házasságának története a Parthenios-gyűjtemény záródarabjaként olvasható (EP XXXVI): a magát a vadászatnak szentelő boldog pár az erdők mélyére vonul vissza a civilizáció elől, ${ }^{97} \mathrm{~s}$ a természetben kiteljesedő szerelmüknek csupán a férj erőszakos halála, majd a feleség azt követő önkéntes éhhalála vet véget. Tragikus végü mítoszuk az ugyancsak a házastársi boldogság alapmotívumára épülő, azonban pozitív végkifejletű első elbeszéléssel, Lyrkos és Hilébia (mint látni fogjuk, az Ió-mítosz hát-

${ }^{94}$ Cf. Georg. IV, 461-462: (...) flerunt Rhodopeiae arces / altaque Pangaea et Rhesi Mavortia tellus / atque Getae atque Hebrus et Actias Orithyia. A Platónnál (Phaidr. 229b-c) is szereplő hagyományra viszszatekintő, Bóreas leányrablását felelevenítő Actias Orithyia szerkezet (463) esetében nincs szó partheniosi megfelelöről.

95 Francese: i. m. (21. jegyz.) 137 vérfertőző testvérszerelmet sejt a történet hátterében.

${ }^{96}$ Servius hallgat Rhésus szerelméről, cf. ad Georg. IV, 462: est prolepsis ex persona poetae: quo enim tempore Orpheus fuit, Rhesus necdum regnabat in Thracia.

${ }^{97}$ Hasonló kezdőpontot találni a félreértés miatt féltékenységi tragédiába forduló X. Parthenios-elbeszélésben is. 
teréből előlépő, önállósuló) történetével kiegészülve narratív keretbe zárja Parthenios

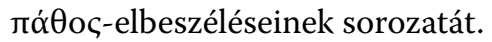

Mindezidáig olyan vergiliusi allúziókról esett szó, amelyek könnyen párhuzamba állíthatók a görög gyűjtemény egyes történettípusaival, természetesen anélkül, hogy Parthenios nyílt vagy kizárólagos hatásáról beszélhetnénk. Egy ilyesfajta közvetlen inspirációs viszony feltételezése a görög és a latin szerző között már csak amiatt sem lehetséges, mert a tanköltemény több más, ugyancsak szerelmi tematikájú, jellegzetes toposzok köré csoportosuló, a mű szerelemfelfogását s így világképét befolyásoló utalásának viszont nem találni előképét az Erótika pathémata lapjain. Amint már elhangzott, Daphné mítoszát kivéve a görög szerzőnél nem olvashatók istenek és emberek intim kapcsolatát bemutató történetek, az elbeszélések szereplői döntő többségükben halandó férfiak és nők. A különböző létszférákat összekapcsoló, ég és föld határán játszódó történetek hiányában nem található meg Partheniosnál például a Zeus földi félrelépéseit megbosszuló, férje áldozatait tönkretevő féltékeny Iuno alakja sem. A vergiliusi szerelmi történettöredékeket ezzel szemben a halandó nők és istenek erotikus kapcsolatának dominanciája jellemzi. ${ }^{98}$ Ami az égi szerető elcsábította s a féltékeny istennő üldözte földi nő történettípusát illeti, annak számos példája olvasható a tankölteményben, illetve annak serviusi kommentárjában. A Nagymedvét formáló csillagokat Servius Hélikével és Kynosurával azonosítja, s az általa felkínált lehetséges változatok szerint a két, Jupiter által elcsábított nővért Junó haragja változtatja égitestekké (I, 264: Arctos Oceani metuentis aequore tingi ${ }^{99}$ ). A Cheirón anyjaként ismert, kancává (más változat szerint hársfává) változtatott Philyra története ugyanezen alaptípussal rokon, azzal az eltéréssel, hogy Servius szerint ez esetben a féltékeny istennő bosszúja helyett a metamorfózis a felesége gyanúját elhessegetni próbáló Kronos intézkedése. ${ }^{100}$

Az üszővé változtatott, örök életű riválisa által folyamatosan gyötört Ió mítoszának vergiliusi felelevenítése esztétikai szempontból is különösen fontosnak bizonyul.

98 Az egyetlen, istennő szerelmét kívánó földi alak a műben a Junó szemérme ellen támadó, s ezért szörnyü büntetést elszenvedő Ixión, cf. Serv. ad Georg. III, 38-39: tortosque ixionis: a quibus religatus ad rotam est, postquam inlicitos Iunonis petivit amplexus. A Georgica egyetlen teljességgel földi, szekularizált szerelmi elbeszélése Héró és Leandros földrajzi eredetmítoszként is szolgáló, néhány soros, a tulajdonneveket elhallgató története (III, 258-263).

${ }_{99}$ Serv. ad. Georg. I, 246: nam hae duae paelices Iunonis fuisse dicuntur: quas postquam Iuppiter in siderum rettulit numerum, Iuno rogavit Tethyn, suam nutricem, ne umquam eas pateretur occidere. unde nunc 'metuentes' dixit, scilicet nutricem Iunonis. sunt autem hae Helice et Cynosura. A variánsok erotikus kiindulópontú, kétfázisú átalakulásról tudnak: Hélikét a féltékeny Junó változtatja medvévé; a szüzességét elvesztő Kynosurát, egykori vadásztársát viszont az ezen felbőszült Artemis. Az ezt követő kettős katasterismos az istenek kegyelmi gesztusa.

100 Serv. ad Georg. III, 92-94: talis et ipse iubam ceruice effundit equina / coniugis aduentu pernix Saturnus, et altum / Pelion hinnitu fugiens impleuit acuto, cf. Serv. ad locum: saturnus dum cum amata Philyra Saturnus coiret, Ops eius uxor advenit. cuius praesentiam veritus, se in equum convertit, qualem potuit numen imitari. exinde natus est Chiron, dimidia parte homo, dimidia equus. (...) quidam Philyram in florem conversam dicunt vel in arborem, unde liber philyrinus dicitur (...) A Philyra-említéshez lásd Nappa: i. m. (71. jegyz.) 127. 
Az utalás az állattenyésztéssel kapcsolatos gyakorlati ismeret, a teheneket vég nélkül kínzó bögöly kapcsán illeszkedik a szövegbe (III, 152-153: hoc quondam monstro horribilis exercuit iras / Inachiae Iuno pestem meditata iuuencae). ${ }^{101}$ A Parthenios-kollekció legelső darabja ugyancsak említi Iót, a szerző azonban a hagyományos, az elcsábításon, illetve átváltozáson alapuló ismert verzió helyett más, meglepő indokot szerepeltet az argosi királylány eltűnése kapcsán: Inachos lányát eszerint kalózok rabolták el. ${ }^{102}$ Parthenios szövege a bevezető mondat után azon nyomban félreteszi Ió szerelmi utalásoktól teljesen megfosztott történetét, hogy helyette a lány keresésére küldött, máshonnan ismeretlen Lyrkos távolról sem tragikus történetére összpontosítson. A férfi kalandjai döntően erotikus találkozásokat jelentenek, s a közérdek (Ió felkutatása) szempontjából sikertelenül végződő vállalkozás Lyrkos magánéleti boldogságában, stabil házasságában ér véget (utóbbit a férj időközbeni, akaratlan félrelépése sem tudja semmissé tenni). ${ }^{103}$ Az Ió-mítosz ezen új, nyilvánvaló fókuszváltás jellemezte változatának a partheniosi gyűjtemény élére helyezése, pontosabban annak mellőzése, a szöveg teréből történő azonnali eltávolítása egy kevéssé ismert történet kedvéért programértékű megnyilvánulásnak is tekinthető. Az Erótika pathémata szerzője az unalomig ismert alaptörténet újbóli ismétlése helyett a hagyomány átalakítására, a mítosz eddig rejtett, vagy valamilyen okból titkolt részleteinek középpontba helyezésére vállalkozik, ez idáig nem jegyzett szereplők és események előtérbe emelésével.

E megközelítés újabb, szemléletes példáját látni a partheniosi Niobé-történetben is (EP XXXIII). A gyermekeit elvesztő anya pszichés alaphelyzetének megtartásával a szerző a megszokottól jelentősen eltérő történetet közöl, a genealógiai adatokon túl számos más elem megváltoztatásával: Niobé, egy vadászbalesetben elhunyt (bizonyára derék) férfi özvegye Létóval verseng, azt állítva, gyermekei szebbek az istennő sarjainál. A szerelmi motívum ezen hybris büntetéseként jelenik meg a történetben: a megözvegyült asszony nem enged saját apja, Assaón vérfertőző vágyainak, aki bosszúból elevenen égeti el unokáit, mire a fájdalomtól megtört anya a tengerbe veti magát. A büntetésként érkező szerelem motívumával a XXVII. fejezet tisztességtelen úrnőjének történetében szintén találkozni, Alkynoé (bűn)bánatában ugyancsak a tengerbe öli magát. Az Erótika pathémata Niobé- és Ió-mítosza alapján a Georgica III. éneke előszavában elhangzó, a mítoszok elhasználtságára utaló költői kérdés - cui non dictus Hylas puer? - rokonítható Parthenios szerzői attitűdjével is.

A tanköltemény mitológiai allúzióiban fellelhető főbb erotikus elbeszéléstípusok áttekintését folytatva említést érdemel az isteni szerelmével kitüntetett szépséges ifjú baleset okozta halálának történetsémája, amelyre a Parthenios-gyüjteményben nem találni példát. A Georgica I. énekének invocatiójában szereplő, a földművelés és az állat-

\footnotetext{
101 Serv. ad Georg. III, 153: pestem meditata ivuencae: Ionem dicit, Inachi filiam, quam in bovem conversam (Iuno) oestro percussisse dicitur. illa se in mare praecipitavit, (quod) Ionium vocaverunt (...)

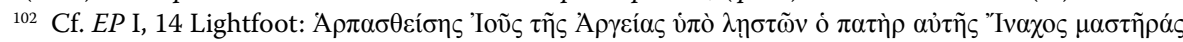

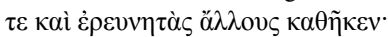

${ }^{103}$ A történetről általában lásd Lightfoot: i. m. (18. jegyz.) 371 skk.
} 
tenyésztés istenségeit soroló katalógusban helyet kap a kezében cipruslombot hordozó Silvanus is (I, 20: et tenaram ab radice ferens Silvane, cupressum). Servius szerint a verssor növénymotívuma az ifjú Kyparissosnak állít emléket. A gyönyörű szarvasa váratlan halála miatt vigasztalhatatlan fiút szeretője, az erdők istene változtatja fává, aki, bár akaratlanul, maga idézte elő az állat pusztulását. ${ }^{104}$ Noha Kyparissos neve nem fordul elő a Parthenios-gyűjteményben (amelynek szerzője, talán valamiféle általános racionalizáló tendencia jegyében, többnyire mellőzi a metamorphosis motívumát), sorsa hasonlóságot mutat az Erótika pathémata szinte mindenkor tragikus vadásztörténeteinek (EP X, XV-XVI, XXXII-XXXIII, XXXVI) szereplöiével. ${ }^{105}$

A méhészeti összefüggésben szereplő, a könnyező nárciszról szóló sorok (IV, 160: narcissi lacrimam) ugyancsak tragikus szerelmi mítoszt idéznek. ${ }^{106}$ A történet nem szerepel az Erótika pathémata sorozatában, noha egy újonnan előkerült fragmentum (P. Oxy 4711 ${ }^{107}$ ) tanúsága szerint Parthenios másutt tárgyalta azt. Ugyancsak a méhek látogatta virágos mező kapcsán esik szó a sötétszirmú jácintról (IV, 183: ferrugineos hyacinthos), amelynek színe a közismert eredetmítosz komorságát hivatott jelezni. Apollón akarata ellenére öli meg földi szeretőjét diszkoszvetés közben, a virág vörösesbarna színe a fiú kiömlött vérének mementója. ${ }^{108}$ A Gallusnak ajánlott gyüjteményben nem szereplő Hyakinthos-mítosz néhány más, homoerotikus vonatkozású átváltozástörténettel együtt olvasható egy ugyancsak Partheniosnak tulajdonított, újabban elökerült papirusztöredéken (P. Oxy. 2723).

Ami végezetül az elemzett szövegek etikai vonatkozásait illeti, az Erótika pathémata esetén nem beszélhetünk rendszeres, egységes etikai tanításról. Bár az 1531-es editio princeps előszavában a kiadó a (keresztény) ifjúság okulására, bűntől való elrettentésére szolgáló gyűjteményként ajánlja az elbeszéléssorozatot, ${ }^{109}$ Parthenios a két egymást követő, naiv királylányok elcsábításáról szóló Odysseus-történettől (EP II-III) eltekintve nem foglal állást szereplői erkölcsiségével kapcsolatban. Csakúgy, mint a majdani költői megformálást, Parthenios az egyes elbeszélések morális dimenziójának megalkotását is

${ }^{104}$ Serv. ad Georg. I, 20: Silvanus deus est silvarum. hic amavit puerum Cyparissum nomine, qui habebat mansuetissimam cervam. hanc cum Silvanus nescius occidisset, puer est extinctus dolore: quem amator deus in cupressum arborem nominis eius vertit, quam pro solacio portare dicitur (...) Az ovidiusi változatban Apollón szerepel Cyparissos isteni szeretőjeként.

105 A kivételesen szép állat váratlan halálával kapcsolatos motívum kibontására az Aeneis VII. énekében, a Silvia mellett megjelenő cervus forma praestanti súlyos konfliktust kirobbantó történetében kerül majd sor.

106 Serv. ad Georg. IV, 160: Allusit ad fabulam, quia de puero est conversus in florem.

107 A partheniosi Metamorphoses töredékeihez (bennük az Adónis-, az Astarté- és a Narkissos-történettel) lásd G. O. Hutchinson: The Metamorphosis of Metamorphosis: P. Oxy. 4711 and Ovid. ZPE 155 (2006) 71 skk., illetve E. Magnelli: On the New Fragments of Greek Poetry from Oxyrhynchus. ZPE 158 (2006) 9 skk. A Narkissos-töredék partheniosi attribúciójának elutasítására lásd H. Bernsdorff: P. Oxy. 4711 and the Poetry of Parthenius. JHS 127 (2007) 1 skk.

108 Serv. ad Georg. IV, 183: Hoc poetice masculino, referens se ad puerum qui in hunc florem dicitur esse conversus.

109 Vö. Lightfoot: i. m. (18. jegyz.) 221. 
az olvasóra, illetve a potenciális újramesélőre hagyja. Ezen, etikailag semleges szerzői álláspont ellenére a szemérem és a szenvedélyek, másutt a magánvágyak és a közérdek közötti konfliktuson alapuló történetekből összeálló sorozat meglehetősen pesszimista képet fest az emberi morálról. ${ }^{110}$ A szerelmi szenvedély s az általa előidézett bűnök felszámolják az egyén akaratszabadságát és józan ítélőképességét, s társadalmi szinten is súlyos következményekkel járhatnak. ${ }^{111}$ Az erotikus természetű kihágások gyakorta még szörnyübb gonosztettek okozóivá válnak (lásd a kannibalizmus és az incestus motívumainak szoros egymásba fonódását, EP XIII, XXXIII $\left.{ }^{112}\right)$. Az ártatlanok életüket vesztik, a gonosztettek elkövetői büntetlenül élnek tovább, a földi vagy az isteni igazságszolgáltatás közbelépése igen ritka esemény (EP XV, XXVII). ${ }^{113} \mathrm{~A}$ vérfertőző apák és anyák (EP V, XI, XIII, XVII, XXXIII), a kegyetlen tyrannosok (XVII) mellett a görög gyüjteményben mindazonáltal találkozni gyermekeiket minden testi megkívánástól mentesen szerető szülőkkel, nemes barbárokkal (VIII - a kelta környezetben játszódó túsztörténet a kelták később, a XXX. fejezetben olvasható eredetmítoszát készíti elő), s a tudtukon kívül vagy az irányíthatatlan szenvedély hatására házasságtörő férjnek megbocsátó nimfákkal, halandó asszonyokkal (I, IV), a haláluk óráján gyilkosukat feloldozó áldozatokkal (XXIV) is. A cselekedetek hagyományos megítélésének, jó és rossz elhatárolásának revíziójára is látni példát: a vérfertőző testvérszerelem, mint azt az Odysseus által elcsábított $\mathrm{s}$ emiatt halálra ítélt Polymélé történetében láttuk, akár életet is menthet (EP II). ${ }^{114}$

A Georgica villanásszerű mitológiai allúzióiban Partheniosnál ismeretlen etikai mélységek nyílnak meg. A rövid görög történetvázaknál is sokkal sűrűbb utalások szemlátomást túllépnek az ornamentika szerepén, s teológiai dimenzióval bővülnek az isteni szereplők $\mathrm{s}$ a létszférák közötti átjárást biztosító átváltozások révén. Vergilius erotikus mítoszallúzióinak további sajátsága az állatvilág felé való nyitás, mindenekelőtt a III. könyv során, amelynek révén a szerelmi történetek beépülnek a tanköltemény egészének filozófiai rendszerébe, az erotikus rớ $\theta$ oc mindenüttvalóságát és mindenhatóságát szemléltetve (III, 244): amor omnibus idem. Az allúziókban megjelenő szerelmi tematikájú eredetmítoszok jelentősen hozzájárulnak a mű világképéhez, egyfajta erotikus kozmogónia felé mutatva, amely a cselekmény szintjén majd a IV. énekben teljesedik ki. A víz alatti palotában játszódó jelenet során az Eurydikét üldöző Aristaios anyja, az Apollón elcsábította, majd elhagyta Kyréné az égiek a világ kezdete óta megesett

110 Megjegyzendő, hogy a Parthenios elleni epigramma ( $A P$ VII, 377 = T 2 Lightfoot) szerzője etikai okokból is kifogásolja annak művészetét, a részleteket lásd Klooster: i. m. (40. jegyz.) 319.

111 A törvénytelen erotikus kapcsolat társadalmi tétjéhez lásd a Periandros-elbeszélést: a bölcs és kiegyensúlyozott athéni politikus az anyja kezdeményezte vérfertőző viszony hatására válik véres zsarnokká ( $E P$ XVII). Egy másik elbeszélés az előbbi, a polis számára végzetes kapcsolat ellentörténetének tekinthető: Hipparinos és Antileón homoerotikus boldogságát megirigyeli a város féltékeny, az ifjak egyikét megkívánó ura, aki azonban az ifjú szerelmesek által elkövetett, a várost felszabadító tyrannocidium áldozata lesz (EP VII).

112 Általánosan megfigyelhető kötődésükről Forbes Irving: i. m. (73. jegyz.) 103.

113 Vö. Klooster: i. m. (40. jegyz.) 314, 19. jegyzet.

114 Az elbeszélés már-már komikus felhangjáról lásd Voisin: i. m. (41. jegyz.) 50. 
szerelmi kalandjait foglalja dalba. ${ }^{115}$ Parthenios elbeszéléseihez hasonlóan a Georgica (cselekménymotívumaikat tekintve kevésbé extravagáns) mítoszai alapvetően tragikus, kegyetlenség, árulás, csalódás áthatotta történetek. Vergiliusnál, csakúgy, mint az Erótika pathémata szerzőjénél, a boldogság nem létező vagy végtelenül sérülékeny, tünékeny mozzanat csupán.

A többé-kevésbé elliptikus szerelmi történetek fontossága a IV. könyvben teljesedik ki, részint Orpheus, Eurydiké és Aristaios történetében, másrészt az annak keretet adó, a kaptár rendjét bemutató leírásban. Vergilius szerint a tiszta, szorgalmas, szervezetten dolgozó rovarok az egyedüli lények, amelyek nem ismerik a nemiség hatalmát, és nincsenek alávetve a szenvedély pusztító erejének. ${ }^{116}$ Utóbbi tény amiatt érdemel figyelmet, mert a szakirodalom régóta hangoztatott, egyöntetű véleménye szerint a méhkas az ideális emberi társadalom előképeként jelenik meg a műben. Az erotikus mítoszallúziók alig észrevehető, a négy könyv szövegében filigránként végigfutó sorozata kevésbé pozitív hangot szólaltat meg a müben, amely (a benne öt alkalommal említett, s minden esetben Jupiterrel társított) Augustus parancsára a munkára, a háború utáni újrakezdésre s egy új társadalmi rend megalkotására kell, hogy buzdítsa a rómaiakat. ${ }^{117}$ Úgy tünik, Vergilius költeménye mitológiai allúzióival e hivatalos állásponton túl az emberlétről, a szabad akaratról s az azt veszélyeztető, annak működését felfüggesztő szenvedélyről való elmélkedésre is hívja olvasóit. A mü szerelemfelfogása a fentebb tárgyalt tragikus történetfragmentumok alapján megegyezni látszik a Bucolica és az Aeneis amorról vallott kijelentéseivel, amelyek állandó eleme a durus, crudelis, improbus, indignus, saevus jelző. Mindennek érdemleges tárgyalásához sokkal nagyobb ívű áttekintés szükségeltetnék. A jelen vizsgálat zárásaként annyi azonban bizonyára kijelenthető, hogy a Georgica rejtett szerelmi elbeszélései jelentékeny részét képezhetik az Erótika pathémata római utóéletének. A két szerző által megidézett mítoszok tanúsága alapján a mezőgazdasági tanköltemény erényes, mindazonáltal impatiens libidinis költőjének képzeletét bizonyára nem csupán a sphragisban megjelenő, immáron néma Szirén táplálta, hanem Parthenios mítoszvázlatai is.

115 Cf. Georg. IV, 344-347: Inter quas curam Clymene narrabat inanem / Vulcani Martisque dolos et dulcia furta / aque Chao densos divum numerabat amores. Vö. Otis: i. m. (20. jegyz.) 138.

${ }^{116}$ Cf. Georg. IV, 197-201: Illum adeo placuisse apibus mirabere morem, / quod neque concubitu indulgent nec corpora segnes / in Venerem solvunt aut fetus nixibus edunt: / verum ipsae e foliis natos, e suavibus herbis / ore legunt (...)

117 Cf. Georg. I, 24-42, 498-514; II, 170-172; III, 16-48; IV, 559-562, lásd még Thomas: i. m. (15. jegyz.) 44 . 


\section{SUMMARY}

At the end of the Georgics (IV, 563-564) Virgil represents himself as someone nursed by sweet Parthenope. According to the Servian tradition, Parthenope would be an allusion to one of the Sirens, patron divinity of Naples-Parthenopolis, place favourit of the poet. Nevertheless, Parthenope used to be considered as well as a self-referential joke on the nickname of Virgil, called Parthenias (a virgin) because of his moral excellence. The paper offers a new metapoetic reading completing the earlier interpretations based on biographical data and local tradition. The allusion should also be regarded as a statement about inspiration. By suggesting a new approach to the mythology, Parthenope seems to create an homage to Parthenius of Nicaea and to his collection of erotic myths. The studies about the impact of the Erotica pathemata on Latin poetry generally focus on the Elegiacs and Ovid. Nevertheless, it cannot be excluded that the mythological allusions of the Georgics may also be influenced by some typical narrative patterns of Parthenius. Virgil's short aetological notes might transmit a concept of human passion, which sometimes is rather similar to the emotional world of the Parthenian narratives, but which is always much more rich in ethical concerns.

Keywords: Parthenius of Nicaea, Erotica Pathemata, Virgil, Georgics, love myths

Pataki Elvira

PPKE BTK Klasszika-Filológiai Tanszék

2087 Piliscsaba, Egyetem u. 1.

pataki.elvira@btk.ppke.hu 